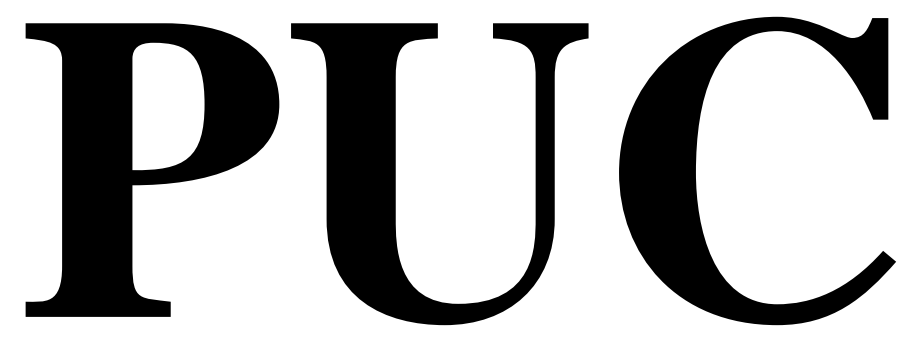

DEPARTAMENTO DE DIREITO

\title{
UM BREVE ESTUDO SOCIOLÓGICO, FILOSÓFICO E JURÍDICO DO GRAFITE \\ Por
}

PEDRO HENRIQUE SOUZA BOAVENTURA

ORIENTADOR(A): RICARDO BRAJTERMAN

2019.1

PONTIFÍCIA UNIVERSIDADE CATÓLICA DO RIO DE JANEIRO

RUA MARQUÊS DE SÃO VICENTE, 225 - CEP 22451-900

RIO DE JANEIRO - BRASIL 


\title{
UM BREVE ESTUDO SOCIOLÓGICO, FILOSÓFICO E JURÍDICO DO GRAFITE
}

\author{
por \\ PEDRO HENRIQUE SOUZA BOAVENTURA \\ Monografia apresentada ao Departamento \\ de Direito da Pontifícia Universidade \\ Católica do Rio de Janeiro (PUC-Rio) para \\ a obtenção do Título de Bacharel em \\ Direito.
}

Orientador(a): Ricardo Brajterman 
Dedico o presente estudo ao meu irmão Paulo Alberto Souza Boaventura que completará 10 anos em que se tornou a razão mais importante da minha vida. Nas palavras de Bernie Taupin na canção "The Greatest Discovery de 1970, musicada por Sir Elton Hercules John: “(...) In those silent happy seconds that surround the sound of this event, a parent smile is made in moments, they have made for you a friend. And all you ever learned from them, until you grew much older, did not compare with when they said "this is your brand-new brother"'" 


\section{AGRADECIMENTOS (...)}

Como diria Bernie Taupin, nas palavras imortalizadas e musicadas por Sir

Elton John no ano de 1967, vindo a ser lançada no segundo trabalho deste em 1970, "It's a little bit funny this feeling inside"

Agradeço, primeiramente, ao meu orientador, Ricardo Brajterman, por ter me dado toda a liberdade criativa no presente feito, além de ter ressignificado minha existência no curso pela possibilidade do diálogo das artes, minha real paixão, com o direito.

Agradeço as minhas incontáveis e incríveis amizades que fiz ao longos destes, atrasados, 6 anos e 6 meses, principalmente aos meus amigos Ulisses Beltrão, Pedro Clarino, Augusto Fontes, Lucas Araujo, Michel Glatt, Nicole Aló, Daniel Mourão, Júlia Triani, Rafaela Delmas, Tatiana Ponzo, Igor Moitinho, Virgínia Andrade, Jessica Sousa, Ana Flávia Verri, Matheus Coutinho, Nathália Borges, Aline Lima, Renato Gomide, Rômulo Martins, João Arthur Bandeira, João Mircilo, Lucas Fleming, Nathália Wantuil, Gabriela Ceccato, Pedro Lucas, dentre tantos outros queridas pessoas que alegraram e compartilharam tanto momentos importantes na minha vida neste período. Ter amigos desta qualidade é uma benção, em seu sentido mais metafísico possível, rara.

Agradeço à minha avó, Judite de Souza Cruz, pela pessoa naturalmente excêntrica que ela é, além de todo amor que me acalma em meus mais desesperantes momentos.

Agradeço a todos momentos célebres e polêmicas em que me vi envolvido e reitero que me diverti em todos os segundos. Não me arrependo de nada. Agradeço à professora Andrea Schettini que, a partir da realização de um trabalho feito em sala, me inspirou a realização deste feito. 
Agradeço pelos ensinamentos e, não menos importante, a amizade dos professores Thiago Varela, Agnes Chirstian, Manoel Peixinho, Adriano Barcelos, Júlia Alexim, Daniela Brandão, Thamis Dalsenter, Fábio Konder, Sérgio Duarte, Felipe Aciolli, dentre tantos outros que fizeram ali espaço de muitas trocas de ideias e experiências de vida.

Agradeço aos meus amigos Manuela Braccini, Max Peter, Daniela Doné, Bruna Rossigneux, Matheus Mayorca, Alexandre Costa, Marianna Ogg, Rodrigo Rosalinski, Pedro Javoski, dentre outros, por todos os momentos, amizade e paciência que têm comigo.

Agradeço ao Sir Elton Hercules John por ter me feito descobrir a música como o encanto que rege a minha felicidade. 
Resumo: tendo em vista a convergência de assuntos envolvendo as artes e o direito, O tema central da presente monografia será a proteção do grafite no direito brasileiro, passando pelos direitos autorais, a diferenciação entre "pixação" e grafite, toda a crítica social que denuncia a repressão ao ato de pichar, a sua criminalização na "Lei de Crimes Ambientais" e, principalmente, o quanto é problemático deixar nas mãos dos juízes a diferenciação do que é pichação (crime) e o que é grafite (arte), fatos estes relacionados ao conceito do que é "arte" e o perfil conservador dos magistrados.

Palavras-chave: Grafite. Arte. Arte Urbana. Pixação. Direitos Autorais. Lei de Crimes Ambientais.

\begin{abstract}
In view of the convergence of issues involving the arts and law, the central theme of this monograph will be the protection of graffiti in Brazilian law, through copyright, the distinction between "graffiti" and "pixação", all social criticism that denounces the criminalization by the "Environmental Crimes Law" and, above all, how problematic it is to leave in the hands of the judges the differentiation of what is "pixação" (crime) and what is graffiti (art), related facts to the concept of what is "art" and the conservative profile of magistrates.
\end{abstract}

Keywords: Graffiti. Art. Urban Art. "Pixação". Copyright Law. Environmental Crimes Law. 


\section{INTRODUÇÃO}

6

\section{CAPÍTULO I - BREVE HISTÓRIA E LUTA DO GRAFITE}

1.1

8

1.2 Da arte urbana e o nascimento do grafite 12

1.3 Grafite como "arte" e cenário nacional 19

CAPÍTULO II - PROTEÇÃO AUTORAL DO GRAFITE 23

2.1 Da tutela dos direitos do autor: instrumentos legais utilizados 23

2.2 Casos Interessantes na Jurisprudência Nacional 37

2.3 Diálogo

com

o direito

comparado 48

CAPÍtUlo III - GRAFITE VS. PICHAÇÃO 51

3.1 Dos conceitos positivados na Lei de Crimes Ambientais 51

\section{CONCLUSÃO}

57

4.1 Do futuro da tutela do grafite: proposta de solução 57

REFERÊNCIAS

BIBLIOGRÁFICAS 59

LISTA

DE

IMAGENS

60 


\section{INTRODUÇÃO}

Iniciando o nosso estudo, é de grande pertinência a conceituação da palavra "arte", entendendo esta como uma antítese de conceito em si já que suas manifestações e formas de expressão revelam-se tão subjetivas como os mais curiosos e misteriosos fenômenos provenientes da expressão humana porém, pela necessidade de traçar uma linha objetiva para o presente trabalho, podemos trata-la como a sublimação de tudo o que o indivíduo experiência na vida e a transforma em manifestações criativas, como a música, o cinema, a literatura, artes plásticas, etc.

A arte urbana, estando em uma zona de penumbra das artes plásticas, é algo totalmente único, regendo-se pelas suas próprias regras, e surge como algo fruto das inconstâncias do meio urbano, utilizando-se de toda a transitoriedade, mutabilidade e diversidade do cotidiano para dialogar com àqueles que usufruem desta forma de viver, como, inclusive, meio de manifestação política.

Um dos conflitos que dizem respeito às artes quanto a tutela do direito é a definição do que seria arte, sendo que nem mesmos artistas e autores saberiam solucionar a questão. Esta definição de conceito abstrato remete à necessidade de se tipificar, própria das leis de proteção aos direitos subjetivos do autor, porém revela problemática do quanto a mesma não estaria limitando algo que em sua própria natureza é ilimitada quanto às suas formas de expressão.

O grafite, sendo uma das maiores bandeiras de representação da arte urbana, manifesta-se em paredes e muros, como forma de intervenção cultural, seja pela crítica política, já que é, em si, desde a sua formação, uma forma de liberdade de expressão daqueles que se encontravam marginalizados em Nova York nos anos 70, seja pela mudança da configuração estética da paleta cinzenta característica da selva de prédios que permeiam todos os centros urbanos, carregando a maior definição do 
que se pode chamar de efêmero e informal que dialoga com o que é o cotidiano de uma metrópole.

A presente monografia busca realizar um estudo sobre os diferentes prismas que perpassam a proteção ao grafite, sendo um privilégio esta oportunidade de investigar sobre diferentes abordagens e o seu diálogo com o direito.

Antes de adentrarmos na esfera legal, faremos um estudo sobre o conceito de arte e, principalmente, a arte urbana, fazendo uma análise histórica dos movimentos que a conceberam e sua realidade atual no contexto nacional com o imprescindível fim de contextualização pois, sem isto, perde-se o fim deste feito.

Ao analisar a sua história e a sua afirmação social de ser "arte", passaremos observar a evolução de como os direitos autorais firmaram-se como o instrumento de sua proteção e como a jurisprudência trata dos litígios e conflitos relacionada aos direitos de imagem e reprodução, fazendo o uso do direito comparado também como análise crítica aos nossos institutos atuais, apresentando, assim, elogios e propostas de soluções à ainda presente problemática que se ergue sobre tal proteção, eis que mostra-se sensível a mesma pelo próprio caráter transitório, público e expositivo que é a "galeria à céu aberto" do Grafite.

Finalizado o estudo dos direitos autorais e o Grafite, não podendo jamais ser omitido, tecerei uma crítica quanto ao poder de discricionariedade dos magistrados em definir o que é arte e o que não é, em outras palavras, o que é grafite e o que é pixação, diferença esta proposta pela Lei de Crimes Ambientais que ainda criminaliza esta, mostrando em clarividência, após o estudo da história de luta social que representa o movimento da arte urbana, quem estas leis buscam atingir, denunciando a discriminatória história que permeia a nossa sociedade.

Promoverei aqui uma dinâmica análise de tudo o que foi dito com o fim didático de firmar a argumentação utilizada e seus pontos, além de ter o privilégio futuro de continuar o presente trabalho. Desde já, agradeço pela 
oportunidade e, finda esta breve introdução, estamos preparados para o começo do estudo.

\section{CAPÍTULO I - BREVE HISTÓRIA E LUTA DO GRAFITE BREVE HISTÓRIA E LUTA DO GRAFITE}

\section{1 "ARTE”}

Antes de começar o presente esforço, faço aqui um manifesto de adoração às artes, razão, esta, que inspira a existência ser algo possível e palatável.

A "arte", entendendo esta como oriundo do processo criativo humano, está presente em, absolutamente, tudo o que nos cerca e esta enorme habilidade, ou "superpoder", é um dos aspectos que nos difere dos demais seres vivos, até onde sabemos.

Afinal, o que é "arte"? Não buscaremos ter a prepotência de responder tal indagação eis que estamos tratando de um dos conceitos mais abstratos, subjetivos e mutáveis que podemos sequer imaginar, porém, nos ateremos a algumas elucidações históricas acerca do tema por fins didáticoexplicativos.

A palavra "arte" é originada do latim "ars" e do grego "techné" que era usada para tratar de qualquer atividade não originada da natureza, sendo esta sua oposição, ou seja, desde trabalhos artesãos à escrita de versos, etc...

Deste elucidado, podemos temos um conceito amplo do sentido da palavra que, empregada em sua forma original, pode-se aferir que qualquer trabalho de origem humana poderia ser classificado como arte, eis que, o humano, se separa da natureza para diferenciar o que dela oriunda e o que este modificou com seu pensamento consciente.

\footnotetext{
${ }^{1}$ SHINER, Larry. "La Invención del Arte”, folha 23. Editora Paidós Estética, 2001.
} 
No século XVIII, a partir de fundamentos da aristocracia da época, ressignificou-se tal narrativa com a criação do conceito de "belas artes", separando-se aqui as artes populares e o artesanato da "verdadeira arte", ou seja, poesia, pintura, arquitetura e música, categorizando aqueles como trabalhos com uma significação menor e inferior, por seu caráter utilitário, tendo uma abordagem mais elitista.

A maior parte dos artistas, anteriores ao século XVIII trabalhavam para seus patrões em um modelo de cooperativa, ou seja, havia a interferência de muitos atores na produção artística, como política, religiosa, etc. Peguemos o exemplo de Leonardo Da Vinci que firmara contratos para pintar suas obras.

A ideia então nova que se criou é que houve uma troca do modelo de "arte" enquanto construção para o de contemplação, ou seja, a estética, sendo um novo paradigma que exclui o funcional em prol do que seria "espiritual transcendente", "contemplação do belo", para o pensamento das elites da época ${ }^{2}$

Principalmente, a partir dos séculos XIX e XX, com a inclusão de novas ideias, como a da fotografia e o cinema, e a elevação destas, inclusive junto à dança, à arte, como algo elevado, houve certas mudanças quanto à temática meramente contemplativa.

Walter Benjamin chamara esta contemplação de "valor de culto", afirmando-se ser algo universal e sempre presente nas artes e, sobre a mudança citada por Larry Shiner, afirmaria decorrer da mudança do culto da arte como instrumento ritualístico religioso, ou seja, "culto à alguma divindade", pelo "culto da arte pela arte", mas não deixando de ser fruto da mesma característica onipresente nas artes ao longo da história.

Conceitos como gênero, cultura, raça e sexualidade, incluídos nos temas dos novos artistas daquela época, buscaram questionar os paradigmas

2 SHINER, Larry. "La Invención del Arte”, folhas 24 e 25. Editora Paidós Estética, 2001. 
vigentes, apontando as discriminações e todo um sistema que legitimava o status quo da marginalização de certos grupos.

O movimento feminista teve um grande papel aqui, fazendo uma releitura das relações de poder, o que era considerado belo pela ótica sexista que permeavam todo um sistema cuja abordagem esteriotipava o sexo feminino, além de, pela maioria dos artistas aceitos no mundo acadêmico, nas galerias e nos museus, era uma história contada a partir do ponto de vista feminino, buscando assim uma constante busca pela inclusão e resgate de artistas ofuscadas pela ótica machista do mundo da arte. ${ }^{3}$

Sobre o citado, para Hans Belting: "Em todo lugar onde se descobre arte feminina, a história da arte é rapidamente ampliada ou reescrita de modo a finalmente atribuir a esse tema suficiente importância."4

Discorrendo sobre o citado, de grande importância se faz as palavras deste autor no livro "A Arte Universal e Minhorias: Uma Nova Geografia da História da Arte”, onde trata de um suposto fim desta.

A arte universal, tal qual a tratada por Larry Shiner, cronologicamente, é uma invenção europeia e norte americana e compreende apenas certos grupos. Ela se materializa numa história comum mundial e disto reagiram as minorias que começaram a questionar a mesma pela exclusão de sua própria história.

O dissenso partia que ora partiu da vanguarda artística que questionavam valores burgueses, culminando na modernidade, hoje é discutida pelo público das artes que cobram o reconhecimento de uma história esquecida, pedindo o revisão e reescritura da mesma pois não veem a sua própria cultura inserida neste contexto, o que chama de "Fim da História da Arte", referindo-se ao conjunto de conhecimentos tratados pela tradicional história da arte.

3 SHINER, Larry. “La Invención del Arte”. Editora Paidós Estética, 2001. fls. 26 e 27 4 BELTING, Hans "A Arte Universal e Minhorias: Uma Nova Geografia da História da Arte" fls. 96 
A bela imagem da história da arte europeia, apesar de ter mantido o monopólio, hoje aparece contestada e desgastada, provocando protestos e de quem não se sentia representada por ela.

Lucidamente, propõe o autor sobre a "invenção da história da arte oficial":

"A disputa em torno da "verdadeira" história da arte é decidida em todas as exposições em que devemos "descobrir" o que não encontramos nas histórias da arte escritas. São exposições promovidas por grupos sociais particulares ou que reagem a eles, isto é, especulam sobre esse público."

O "velho", ou tradicional, estilo compreende o ciclo que vai da antiguidade até a modernidade, segundo "ritos próprios de uma cultura própria que não podem ser, simplesmente, transferidas a outras. Para aquelas culturas onde não houve processos similares, não se pode aplicar o mesmo modelo europeu-estadunidense como sendo algo semelhante.

O projeto ocidental da modernização tecnológica é grande responsável pela problemática porque consagra a ideia de uma cultura mundial, sendo uma ameaça à diversidade cultural pela retórica do universalismo, eis que este não reconhece a diferença entre proximidade e distância, tratando, menorizadamente, os conflitos resultantes disto como meras "crises de adaptação" à globalização, que sempre vem acompanhada da importação de mídias ocidentais. Completando o autor: "No fundo tratase de uma colonização com outros meios e ela oferece o cenário artístico apenas a seguinte escolha: take it or leave it (pegue-o ou deixe-o). Aí também são permitidas especificamente "propostas étnicas" nas mídias imagéticas, pois proporcionam para o Ocidente antes de tudo um álibi desejado"5

Conclui, assim, Hans Belting sobre o equívoco de nossos métodos tradicionais pois é evidenciada a sua impossibilidade de tratar, sob as

5 BELTING, Hans “A Arte Universal e Minhorias: Uma Nova Geografia da História da Arte" fls. 99 
mesmas perspectivas, a pré-história, assim como as histórias de quaisquer outras culturas, denunciando a tentativa desta de faze-lo de mera invenção.

Tratando, como referência do "Diasporis Manifesto (1989) do artista judeu Ronald B. Kitaj, trata do "fim da arte" como: "Uma diáspora segundo a qual se vive sempre no estrangeiro e se tem de procurar para si uma identidade, pois não se possui uma e também não se adquire uma no cenário artístico global, embora ai se possa, em todo caso, assimilar uma identidade. ${ }^{6}$ Como se sabe, entre os antigos judeus a proibição da imagem não era tão judaica. Pelo menos até a fundação do Estado de Tel-Aviv quase todos os judeus viveriam em diáspora, onde encontraram em sua arte um médium para a identidade, a qual estava sempre ligada à religião. Hoje vale para todos que "não se sentem em casa" e querem, por isso, filiar-se a um grupo com convicções comuns. A "arte da diáspora", com cujo conceito Kitaj brinca irônica e melancolicamente, é a contrapartida da assim chamada arte universal e usurpa exatamente aquela consciência de identidade que durante muito tempo estava associada à história da arte ocidenal.",7

Eu aposto que, a partir deste contexto de reinvidicações das minorias em ter sua história da arte reconhecida, "diáspora da arte" contra o status quo das belas artes, você pensou no Grafite. É esta linha que seguiremos.

\subsection{DA ARTE URBANA E O NASCIMENTO DO GRAFITE}

A origem do que consideramos "Graffiti" é de difícil consenso, eis que o ser humano, ao longo da história, se expressa desde os seus

\footnotetext{
${ }^{6}$ BELTING, Hans "A Arte Universal e Minhorias: Uma Nova Geografia da História da Arte" fls. 96, 97

${ }^{7}$ Ibidem, fls. 104
} 
primórdios por representações de múltiplos gêneros em espaços públicos, porém pode ser discutido suas peculiaridades e diferenças estéticas ao longo desta trajetória.

Começamos aqui com a palavra "Graffiti" que tem surgimento em meados do século XIX como uma leitura da palavra italiana "sgraffiti", contemporânea às descobertas feitas em Pompéia, quais sejam as inscrições feitas em suas paredes.

A conotação do termo no sentido que compreendemos atualmente que relaciona-se, intimamente com a ideia de democratização das artes se dá no início do século XX com a "pintura mexicana mural".

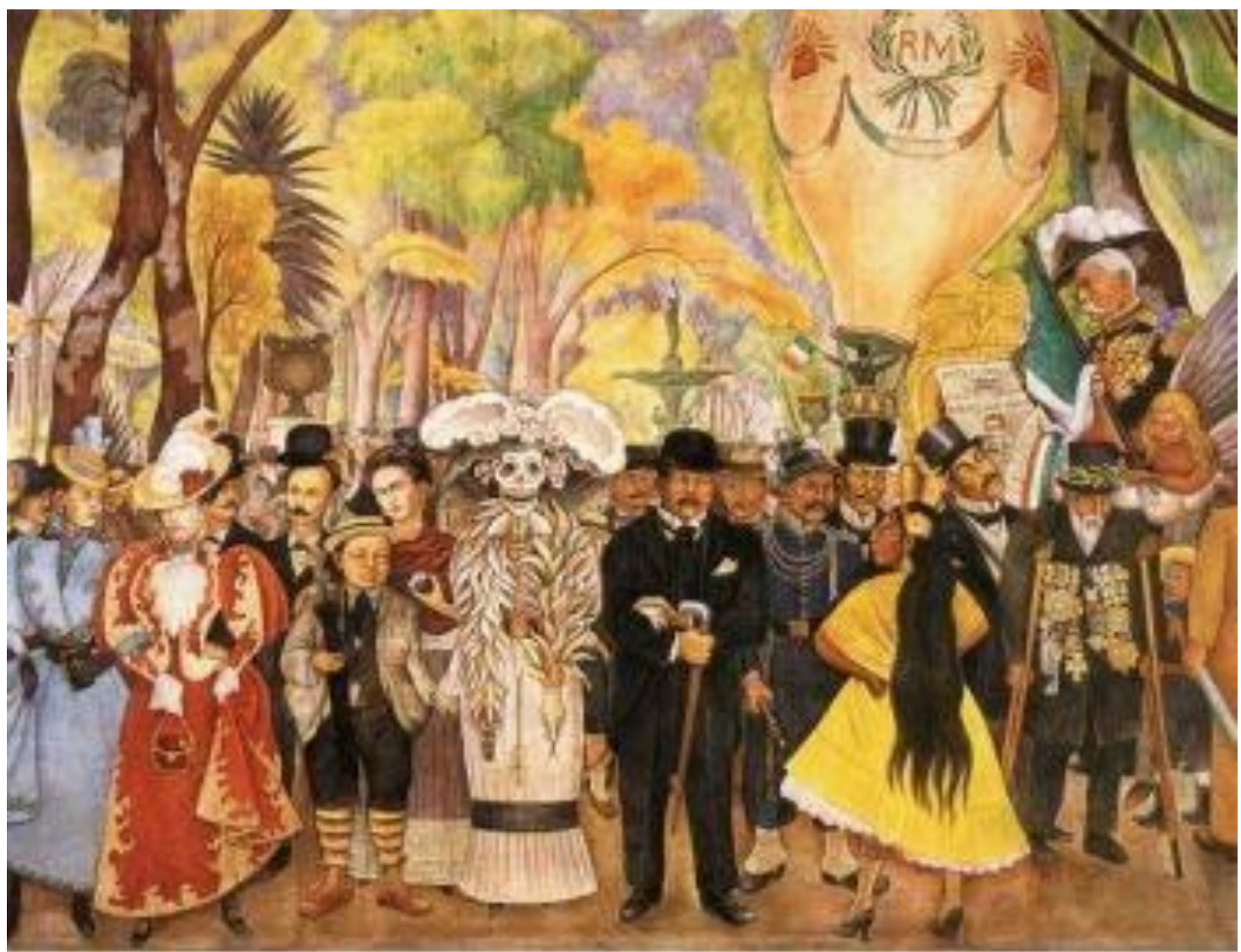

Figura 1

No período citado, o México era procurado por uma gama de artistas da época na busca de novas direções artísticas. Ideias de um

8 "A origem deste termo é uma reminiscência do vocábulo italiano sgraffire. Assim, o sgraffiti é uma técnica de decoração de fachadas, segundo o qual se sobrepõem várias camadas de estuque; antes de secar, o artista faz incisões em forma de linha [...]" (STAHL, 2009, p.6) 
movimento artístico/político cujo manifesto era de uma arte que pudesse dialogar com as massas, comandado por pintores como Diego Rivera, José Clemente Orozco e David Alfaro Siqueiros, com seus enormes murais dispostos em edifícios públicos, chamava a atenção de toda esta classe em nível mundial.

Na década de 30, surge um artefato que mudaria a vida do Graffiti para sempre: O "spray". O movimento cumpriria, finalmente, o seu objetivo com um equipamento mais barato e prático e penetraria no linguajar das ruas pelo seu fácil acesso.

Desde a metade do Século XX, o uso do "spray" foi incorporado por todos os setores, sendo o instrumento de expressão do descontentamento contra as injustiças sociais em épocas "pré-mídia social", transgredindo os espaços urbanos com mensagens críticas de vozes de negros, latinos e quaisquer grupos que eram marginalizados pelos instrumentos opressores de uma sociedade elitista que os rejeitava.

Focando no exemplo americano, até para entender a nossa variação do movimento que teve este como a principal influência, o Graffiti foi chamado nos Estados Unidos de "spray art", tendo o seu espaço de interferência em muros, vagões de trens, estações de metrô, etc.

Contextualizada em um ambiente de convulsão social, Nova York era uma panela de pressão prestes a explodir nos anos 70: Um crescente processo de exclusão social e um desenvolvimento vertical da cidade, contrastando com bairros marginalizados, onde, principalmente, negros e latinos residiam, além de recorrentes ondas de violência; O cenário ideal para um processo que busca voz e choque contra essa indiferença de uma metrópole elitista. ${ }^{9}$

\footnotetext{
${ }^{9}$ COUTINHO BISSOLI, Daniela. "GRAFFITI: PAISAGEM URBANA MARGINAL A INSERÇÃO DO GRAFFITI NA PAISAGEM URBANA DE VITÓRIA (ES)” 2011. Fls. 34,35 .
} 
Os grafiteiros nova-iorquinos se dividiam em "crews" estes a inscrições de seus nomes de identificação pelo cenário urbano da cidade que foi apelidado de "lettering", com inspiração gráfica em quadrinhos, algo como um paralelo, ao menos na função, do que chamamos de pichação no Brasil, tendo duas vertentes com o "tag" (linhas simples) e o "bomb" (escrita com um maior volume). Fazendo outro paralelo aos nossos "pichadores", os responsáveis pelo movimento do "lettering" eram simplesmente chamados de "writers".

As mensagens escritas eram um manifesto contra ao status quo da exclusão socia nova iorquina, assim como se mantém até hoje nos manifestos do Graffiti. Eram a linguagem da rua sendo inscrita por onde estas ruas cruzavam como um grito por visibilidade, pela existência negligenciada, contra o genocídio negro, contra as drogas, contra as discriminações sociais como um rompimento do submundo que emerge como uma explosão, colorindo e escrevendo nas cidades tudo aquilo que por muito tempo deixavam por debaixo dos planos do american way of life de uma população que não gozava dos privilégios que eram vendidos desta sociedade hipócrita americana.

O sistema, como sempre o fez com aqueles que excluem, tentou calar os grafiteiros com prisões, proibições do uso de spray, mas uma vez que a panela estoura, não há caminho de volta e esta liberdade ofensiva, questionadora, subversiva o repetia no dia seguinte: O Graffiti se define como parte do urbano.

Writers, como TAKI, com suas inscrições de "TAKI 183", se tornaram, cada vez mais, frequentes, impulsionados pela cultura do gueto do Hip-Hop, trap e o rap, fizeram um o ambiente perfeito para uma efervescência do movimento, assim como um ambiente de proteção e identificação para aqueles que compartilhavam deste grito, culminando com o cenário do Pop Art, que foi fundamental para a defesa do movimento.

\footnotetext{
10 "As crews eram grupos formados por grafiteiros, denominação que perdura até hoje inclusive no Brasil"
} 


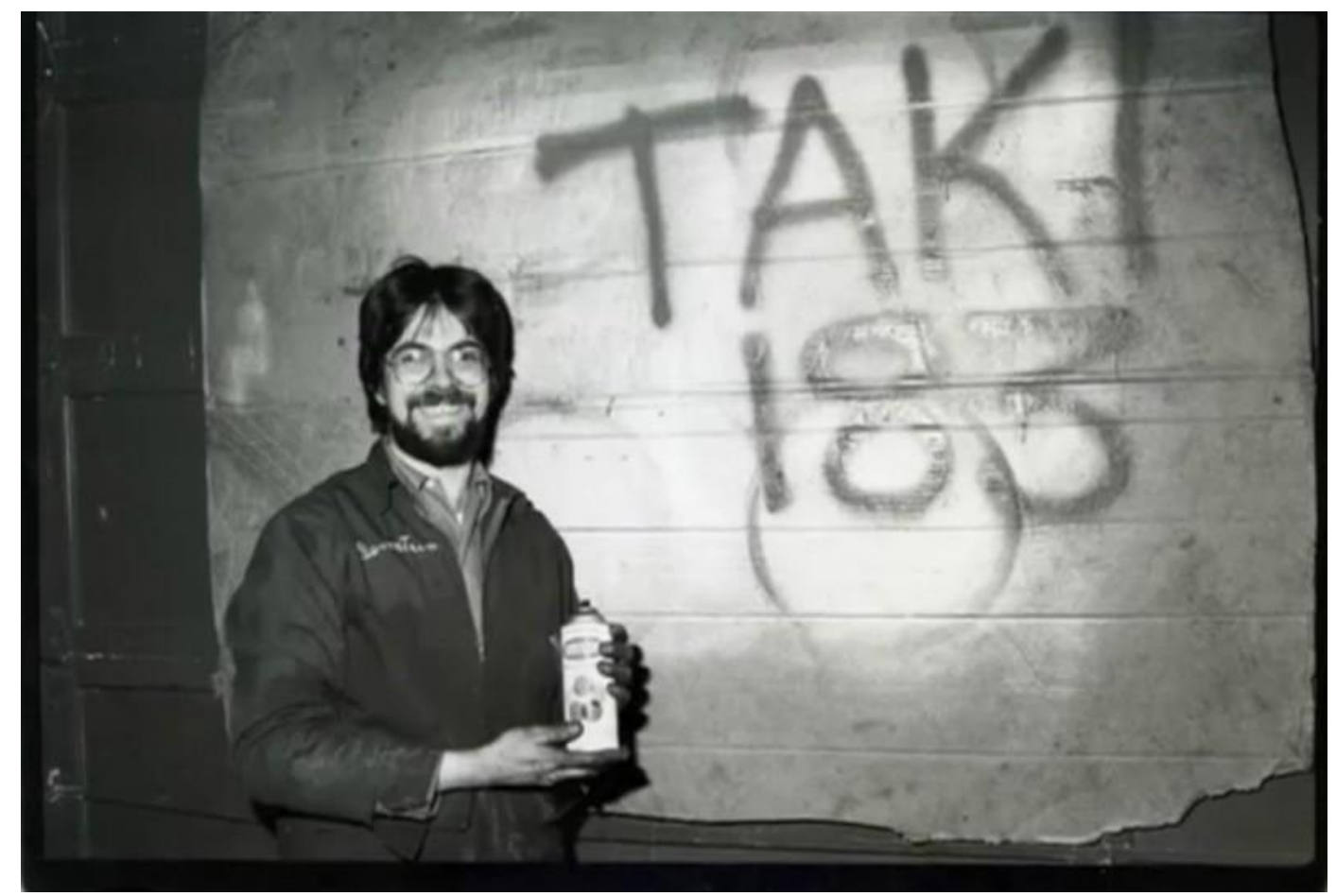

Figura 2

Jean-Michel Basquiat foi um dos grandes expoentes do movimento nova-iorquino e, protegido por Andy Warhol, conquistou o cenário artístico da época, marcando a transição do Graffiti dos muros às galerias de arte.

Sob o pseudônimo enigmático de "SAMO", fazia intervenções em Manhattan, principalmente, perto de galerias de arte, como um contraste claro entre o marginal e o elitizado. 


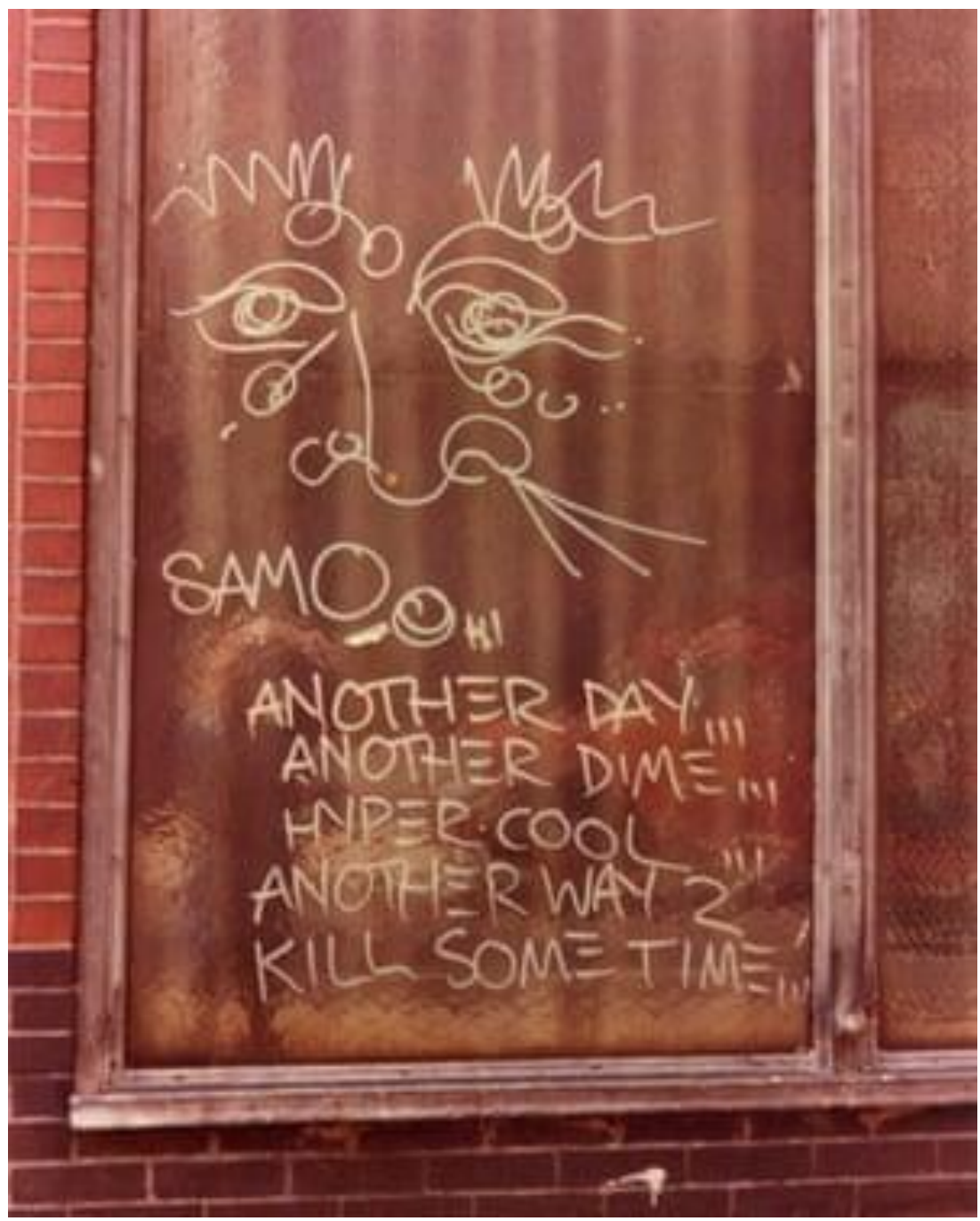

Figura 3

Outro grande expoente do período foi Keith Haring que, dos muros de metrô e painéis urbanos, ou seja, os muros da cidade, conquistou, não somente as galerias, como surfou no movimento do "Art Pop" de Warhol e seus bonecos e entrelaçados labirínticos viraram um grande fenômeno cultural, virando estampas de camisas e canecas, principalmente comercializadas na sua loja chamada "Pop Shop", localizada no "Soho", Nova Iorque. 


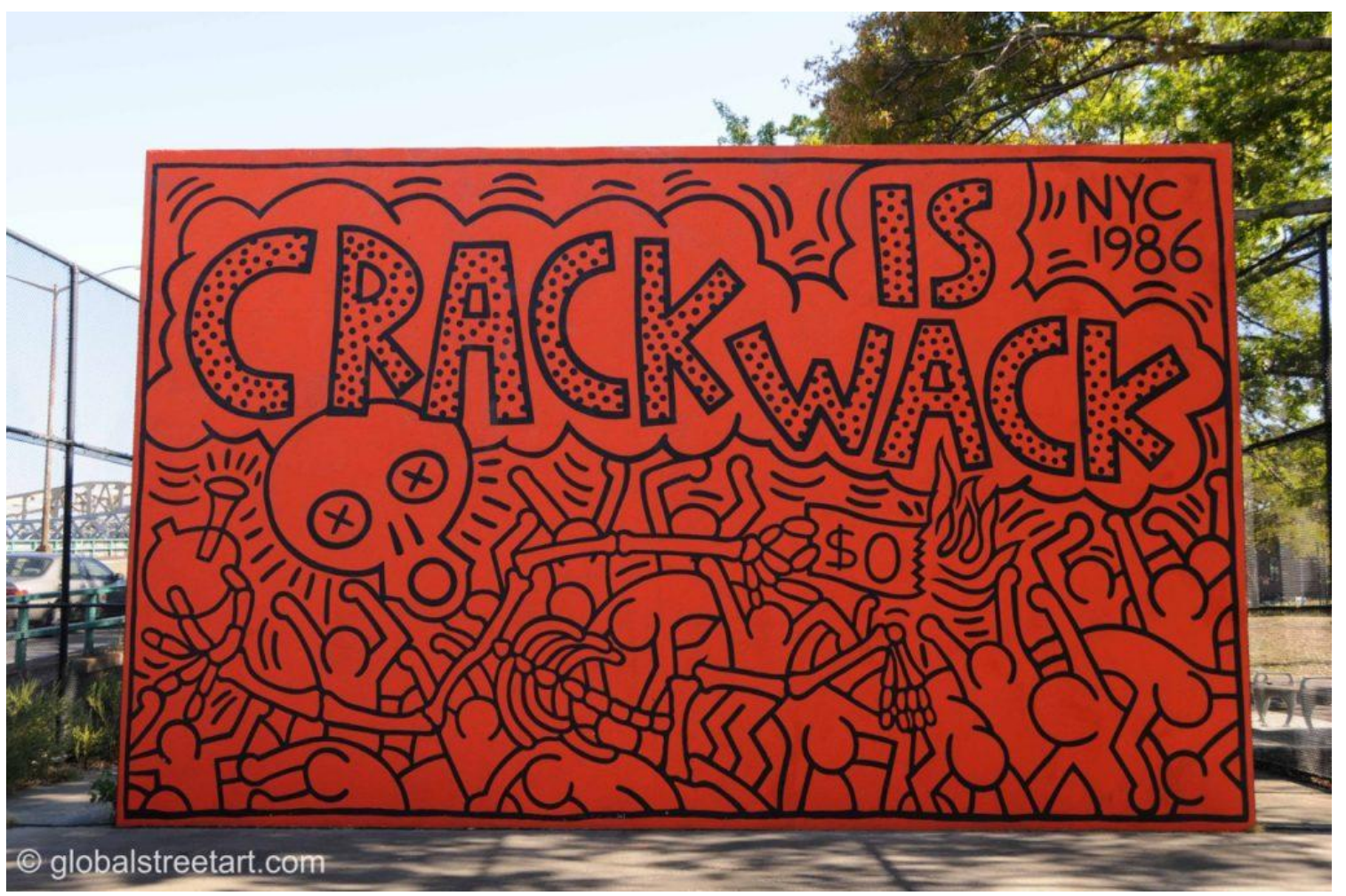

Figura 4

Vale destacar que o Graffiti é a arte que dialoga com o urbano interferindo em suas cores, paisagens e dialogando com o fenômeno do transitório, eis que é sujeito ao desgaste do tempo e, quando chega às galerias, está sendo vendida ali não o próprio, porém a sua estética. ${ }^{11}$

\subsection{GRAFITE COMO “ARTE” E CENÁRIO NACIONAL}

Nas últimas décadas, a arte de rua brasileira, especialmente o grafite, vem conquistando bastante destaque no cenário internacional. A cidade de São Paulo tornou-se um destino de grande parte dos grafiteiros estrangeiros pela enorme quantidade de intervenções e estilos que são perceptíveis por todas as partes.

\footnotetext{
${ }^{11}$ COUTINHO BISSOLI, Daniela. "GRAFFITI: PAISAGEM URBANA MARGINAL A INSERÇÃO DO GRAFFITI NA PAISAGEM URBANA DE VITÓRIA (ES)" 2011. FIs. 3640.
} 
É de conhecimento notório que o Brasil é uma nação culturalmente e etnicamente extremamente diversa e o "Graffiti" nacional reflete tal qualidade pois este funciona como um espelho reativo ao cotidiano urbano.

Próxima à figura dos "writers", temos aqui os "pixadores": seres ousados e criados por um país de extrema desigualdade, principalmente quando trata-se a respeito de um grande metrópole igual São Paulo, onde classes sociais contrastam-se por desigualdades absurdas cotidianamente, que se arriscam das mais diversas formas para buscar a sua voz, deixando as suas marcas nos prédios, muros e diversos outros painéis urbanos em um país onde o racismo e a violência policial contra a população de baixa renda e, majoritariamente, negra, é extremamente marginalizada.

$\mathrm{Na}$ pixação podemos traçar completos paralelos com o "tag" e o "bomb", eis que, nos anos 80 principalmente, teve bastante influência de movimentos internacionais, principalmente o nova-iorquino

Um dos grandes expoentes do grafite nacional foi Alex Vallari que, nos anos 70, distribuiu pela cidade de São Paulo as suas marcas, como a "Bola Preta" e mulheres com trajes íntimos, assim como a sua famosa personagem "Rainha do Frango Assado". A importância de Vallari foi tamanha que o dia 28 de Março, data do falecimento do mesmo em decorrência de HIV em 1987, tornou-se o "Dia Nacional do Grafite". Junto do mesmo, Carlos Matuck e Waldemar Zaidler foram os primeiros grafiteiros reconhecidos como tais e entrar, assim nas galerias de arte da cidade. 


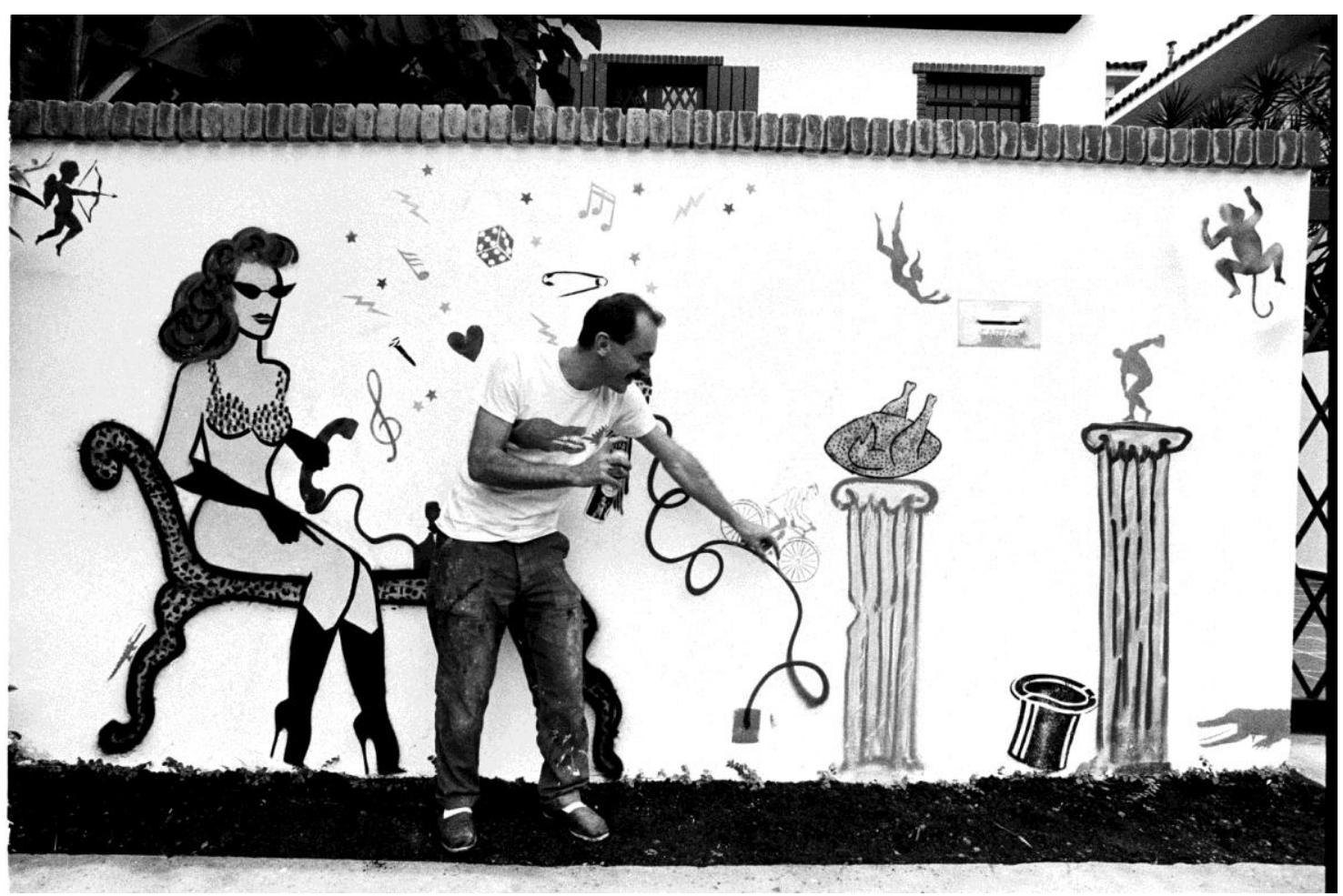

Figura 5

Uma das cenas mais marcantes de intervenção de grafite na cidade foi feita pelo grupo "3nós3", formada por companheiros de Vallari, quando colaram um " $\mathrm{X}$ " feito por fita crepe nas principais galerias da cidade com os seguintes dizeres: "O que está dentro fica, o que está fora se expande", fazendo uma clara crítica ao elitismo e segregação que envolve o universo comercial das "Belas Artes". 12

A década de 80 no Brasil é marcada pela influência dos movimentos de arte de rua americanos, incluindo aqui o hip-hop e a cultura do "skateboard. Uma amostra do mesmo é a presença de John Howard, grafiteiro americano que mudou-se de São Francisco para São Paulo, criando oficinas para jovens, dentre estes, alguns eram pixadores, contribuindo para a democratização da linguagem e forma de expressão nas ruas da cidade.

Seguindo a tendência mundial, a estética do "Graffiti" brasileiro saiu das ruas para as galerias, tendo o seu movimento ampliado para todo o

\footnotetext{
${ }^{12}$ COUTINHO BISSOLI, Daniela. "GRAFFITI: PAISAGEM URBANA MARGINAL A INSERÇÃO DO GRAFFITI NA PAISAGEM URBANA DE VITÓRIA (ES)” 2011. FIs. 42, 43.
} 
território, com destaque para as cidades de São Paulo, Rio de Janeiro e Belo Horizonte.

Um dos exemplos de maior reconhecimento do grafite nacional, atualmente, são as obras de "Os Gêmeos", formado pelos irmãos Gustavo e Otávio Pandolfo, tendo como grande características os seus personagens de tons amarelados para representar o "queimado pelo sol", com referências à figura dos nordestinos, com a presença de muitos objetos e uma explosão de cores para simbolizar a população marginalizada do país, como aqueles que migram do Nordeste para tentar a sorte nas grandes metrópoles, retratados com a expressão de dor das dificuldades cotidianas, tendo obras espalhadas pelo mundo como, além de São Paulo, Portugal, Alemanha, França e Estados Unidos.

Detentor do recorde de maior grafite pintado no mundo com um painel em homenagem ao chocolate de 5.742 metros quadrados às margens da Rodovia Castello branco na Região Metropolitana de São Paulo, Eduardo Kobra também se destaca como um dos maiores expoentes do grafite nacional, tendo começado como pixador nas periferias paulistas. Sua obra é marcada com obras hiper-realistas acompanhadas com uma diversidade de cores em contraste que buscam, assim, chamar atenção, retratando grandes personalidades como Salvador Dalí e Oscar Niemayer. O seu trabalho é grande reconhecimento internacional, tendo, inclusive, pintado a obra "Etnias" para a as Olimpíadas do Rio de Janeiro, em 2016, como parte do projeto de revitalização da Zona Portuária Carioca. ${ }^{13} 14$

\footnotetext{
${ }^{13}$ http://www.eduardokobra.com/biografia/

${ }^{14}$ COUTINHO BISSOLI, Daniela. "GRAFFITI: PAISAGEM URBANA MARGINAL A INSERÇÃO DO GRAFFITI NA PAISAGEM URBANA DE VITÓRIA (ES)” 2011. Fls. 43,44
} 


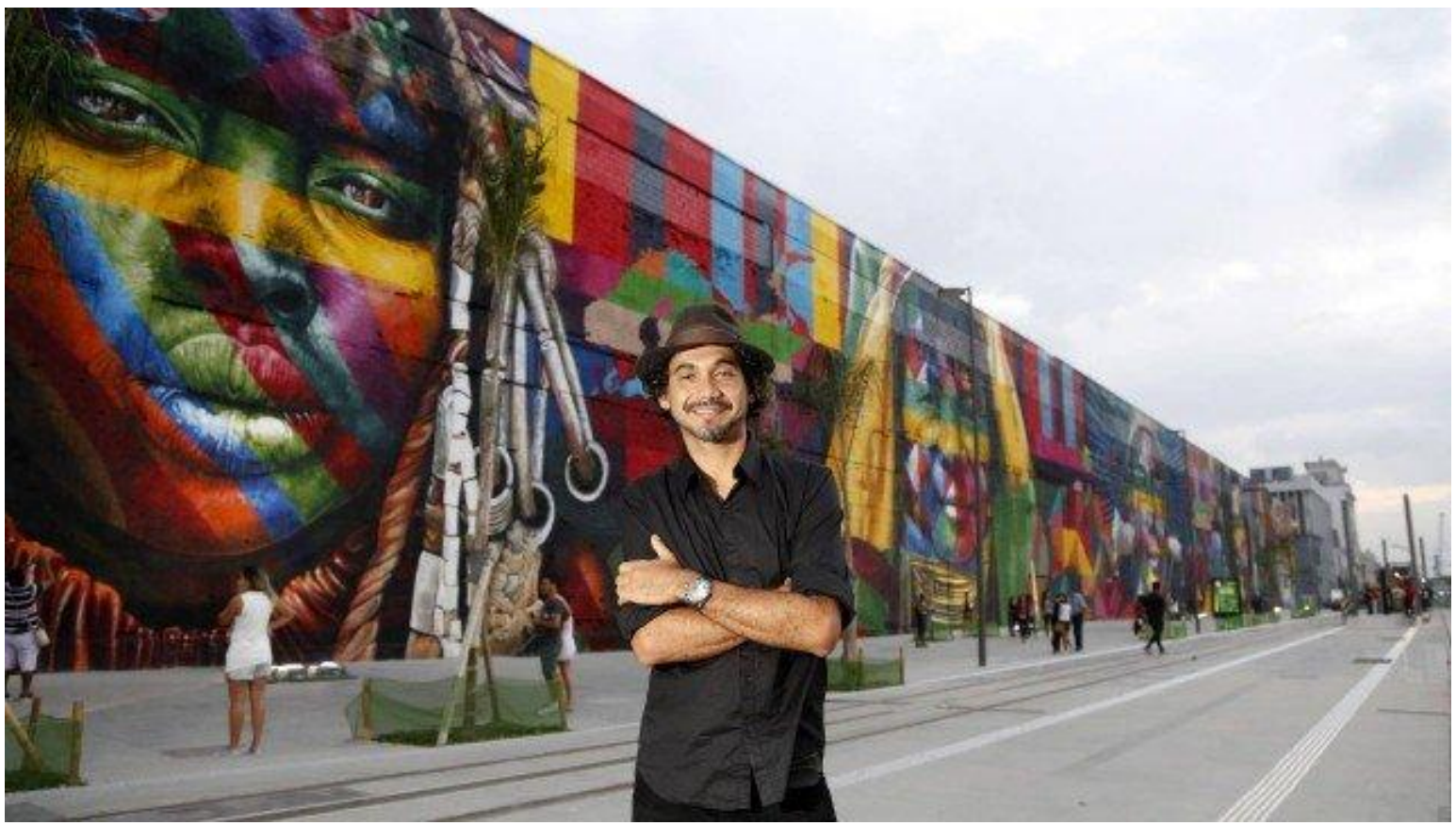

Figura 6

Ainda na cidade de São Paulo, não podendo não ser dito, temos um dos grandes símbolos do grafite nacional, a considerada galeria ao céu aberto na Vila Madaleno, na região de Pinheiros, chamada de "Beco do Batman".

Nos anos 80, a estética do grafite já havia adentrado nas galerias, no mercado da arte e, por consequência, no mundo acadêmico. Na região hoje conhecida como "Beco do Batman" havia um desenho caricato do herói, hoje não mais existente devido a sobreposição feita por outros grafiteiros, cuja autoria era desconhecida, mas o fato atraiu a atenção de muitos estudantes de artes que deram início à ocupação do lugar como uma área livre para explorar o Grafite. Atualmente, apesar de ter se perdido o original, há um vitral de um imóvel localizado no beco com a sua estampa cravada. $^{15}$

Um projeto atual de destaque nacional que busca proteger a memória do grafite é o projeto "Street Art-Rio", fruto do transbordamento da arte de rua paulista para outros cantos do país, se destaca com imensa

\footnotetext{
${ }^{15}$ https://super.abril.com.br/blog/oraculo/por-que-o-beco-do-batman-em-saopaulo-tem-esse-nome/
} 
inovação no que diz respeito à memória do grafite carioca. Sua ideia central, em contrapartida à característica sempre presente da transitoriedade dos desenhos que contrastam com a cidade, é catalogar a maior quantidade das artes espalhas por todo o Rio de Janeiro, tendo uma plataforma fácil e simples de navegar onde pode-se ver a obra, artista e localidade, impedindo que sua memória se entregue à efemeridade. ${ }^{16}$

\section{CAPÍTULO || - PROTECÃO AUTORAL DO GRAFITE}

\subsection{DA TUTELA DOS DIREITOS DO AUTOR: INSTRUMENTOS LEGAIS UTILIZADOS}

Iniciaremos agora com o estudo jurídico sobre a tutela do Graffiti no ordenamento jurídico brasileiro, algo que, pela sua própria natureza transitória encontra dificuldade com os mecanismos legais atuais, comecemos pelo fato de não haver tipos específicos sobre o tema nem doutrina o suficiente para podermos ter um conhecimento minimamente completo, porém, observando a jurisprudência nos últimos anos, podemos traçar uma analogia com as figuras já existentes, principalmente na lei de direitos autorais (Lei 9.610/98).

Em sua origem, qual seja 1710, as leis de direito autoral surgiram como forma de proteger e promover a criação científica, artística e cultural, em contrapartida do poder econômica ao que o autor se submetia perante os empresários.

Um dos primeiros institutos criados neste sentido, o Copyright, de origem inglesa e, posteriormente, importada pelos norte-americanos através da Copyright Law, destinava a proteção ao autor em detrimento do editor, dando àquele o direito exclusivo da impressão.

\footnotetext{
${ }^{16}$ http://streetartrio.com.br/o-projeto/
} 
De forma a expandir e elaborar o Instituto, o direito francês, através do "Droit d'Auteur" foi proferida, pela primeira vez a expressão tal qual utilizamos atualmente, qual seja o "Direito do Autor", protegendo, individualmente este perante a sua obra. ${ }^{17}$

O "pontapé” inicial na proteção aos direitos do autor, no Direito Internacional, foi a "Convenção de Berna para a Proteção das Obras Literárias e Artísticas”, ou, simplesmente, "Convenção de Berna”, de 9 de Setembro de 1886, confirmando-se até os dias atuais como o principal dispositivo do direito internacional sobre o tema, sendo promulgada pelo Brasil, na então Ditadura Militar, em 6 de Maio de 1975 pelo decreto n 76.699, confirmando o compromisso nacional na proteção aos direitos do autor, tendo, desde então, uma forte influência na legislação dos nossos dispositivos sobre o tema.

Vejamos o seu artigo segundo, parágrafo primeiro:

“Artigo 2

1) Os temas "obras literárias e artísticas", abrangem todas as produções do domínio literário, cientifico e artístico, qualquer que seja o modo ou a forma de expressão, tais como os livros, brochuras e outros escritos; as conferências, alocuções, sermões e outras obras da mesma natureza; as obras dramáticas ou dramático-musicais; as obras coreográficas e as pantomimas; as composições musicais, com ou sem palavras; as obras cinematográficas e as expressas por processo análogo ao da cinematografia; as obras de desenho, de pintura, de arquitetura, de escultura, de gravura e de litografia; as obras fotográficas e as expressas por processo análogo ao da fotografia; as obras de arte aplicada; as ilustrações e os mapas geográficos; os projetos, esboços e obras plásticas relativos à geografia, à topografia, á arquitetura ou às ciências. ",

Analisando o seu artigo segundo, moderno e lúcido até os dias atuais, é clarividente que teve a graça de tecer um rol não taxativo, eis que o

\footnotetext{
${ }^{17}$ BARBOSA, Denis Borges. "Direito Autoral e Liberdade de Expressão Estudos de Direito", 2005. P. 95.
} 
processo artístico, suas formas, meios e técnicas, estão em constante movimento de mudança e atualização, sendo um processo histórico reativo às realidades, ao contrário, o faz de forma exemplificativa das formas de artes que existiam até então, anteriores à massificação do Graffiti em todo o globo, que serão tuteladas, não sofrendo, assim, pelo anacronismo do tempo

Conforme exposto, antes de entrarmos no mecanismo jurídico específico, não podemos deixar de citar aqui a Constituição Federal que, em seu artigo 5, inciso XXVII, trata dos direitos autorais:

"Art. $5^{\circ}$ Todos são iguais perante a lei, sem distinção de qualquer natureza, garantindo-se aos brasileiros e aos estrangeiros residentes no País a inviolabilidade do direito à vida, à liberdade, à igualdade, à segurança e à propriedade, nos termos seguintes:

XXVII - aos autores pertence o direito exclusivo de utilização, publicação ou reprodução de suas obras, transmissível aos herdeiros pelo tempo que a lei fixar;"

O artigo citado será a base para a interpretação dos direitos autorais no ordenamento vigente e, nele, é elevado à ordem fundamental os direitos de reprodução do autor com a sua obra, sendo invioláveis.

Ao longo do estudo feito baseado na jurisprudência brasileira, constata-se que a maior parte das controvérsias relativas ao Graffiti perpassam sobre a Lei 9.610/98, qual seja, a Lei dos Direitos Autorais.

Com a entrada das artes de rua na "Cultura Pop", sendo consequência disso a massificação da estética do Graffiti e sua entrada nos principais centros de artes plásticas do mundo, como galerias e museus, é natural que comecem a surgir questões próprias e, principalmente, quanto aos usos de imagem das obras.

A confusão criada pelo Graffiti ao instituto é o fato deste utilizar-se do espaço público, o que causa estranhamento por sua natureza quando pensamos nos direitos morais do autor, por exemplo. Fato que é evidenciado nos acórdãos é o reconhecimento do mesmo como arte e, assim como quaisquer outras formas, é feita a analogia com a lei de direitos.

Vejamos o artigo 7 da lei de direitos autorais: 
“Art. $7^{\circ}$ São obras intelectuais protegidas as criações do espírito, expressas por qualquer meio ou fixadas em qualquer suporte, tangível ou intangível, conhecido ou que se invente no futuro, tais como:

I - os textos de obras literárias, artísticas ou científicas;

II - as conferências, alocuções, sermões e outras obras da mesma natureza;

III - as obras dramáticas e dramático-musicais;

IV - as obras coreográficas e pantomímicas, cuja execução cênica se fixe por escrito ou por outra qualquer forma;

$\mathrm{V}$ - as composições musicais, tenham ou não letra;

VI - as obras audiovisuais, sonorizadas ou não, inclusive as cinematográficas;

VII - as obras fotográficas e as produzidas por qualquer processo análogo ao da fotografia;

VIII - as obras de desenho, pintura, gravura, escultura, litografia e arte cinética;

IX - as ilustrações, cartas geográficas e outras obras da mesma natureza;

$\mathrm{X}$ - os projetos, esboços e obras plásticas concernentes à geografia, engenharia, topografia, arquitetura, paisagismo, cenografia e ciência;

XI - as adaptações, traduções e outras transformações de obras originais, apresentadas como criação intelectual nova;

XII - os programas de computador;

XIII - as coletâneas ou compilações, antologias, enciclopédias, dicionários, bases de dados e outras obras, que, por sua seleção, organização ou disposição de seu conteúdo, constituam uma criação intelectual.

$\S 1^{\circ}$ Os programas de computador são objeto de legislação específica, observadas as disposições desta Lei que lhes sejam aplicáveis.

$\S 2^{\circ}$ A proteção concedida no inciso XIII não abarca os dados ou materiais em si mesmos e se entende sem prejuízo de quaisquer direitos autorais que subsistam a respeito dos dados ou materiais contidos nas obras.

$\S 3^{\circ}$ No domínio das ciências, a proteção recairá sobre a forma literária ou artística, não abrangendo o seu conteúdo científico ou técnico, sem prejuízo dos direitos que protegem os demais campos da propriedade imaterial.”

O dispositivo supracitado, segundo um rol exemplificativo, ou seja, não taxativo, de forma similar ao que faz o artigo 2 parágrafo 1 da Convenção de Berna, positiva que a tutela do mesmo destina-se a qualquer forma de obra intelectual criada, podendo ser fixada em qualquer meio, de 
acordo com o caráter caótico e desforme, metaforicamente, que a arte pode se manifestar, estando de acordo com a mutabilidade desta e, desta forma, inclui-se aqui o Grafite. Nas palavras de Denis Barbosa:

"O copyright e os direitos de autor não podem ser utilizados para restringir quaisquer obras funcionalmente equivalentes: por definição, as obras literárias, artísticas ou científicas não têm qualquer funcionalidade além do seu objetivo de expressão. Tais criações são produzidas com a finalidade de expressar idéias, conceitos e sensações, todas elas com circulação livre de qualquer restrição jurídica" ${ }^{18}$

A importância da utilização do referido mecanismo para os autores das obras de Grafite é um grande avanço no que diz respeito ao reconhecimento deste como arte, algo fruto de uma batalha de gerações destas vozes que não se encontravam nos mecanismos de expressão da sociedade, estando, na sua origem, afastados de toda a discussão do que se entende como obra artística, algo que não pode abster-se de pronunciar.

Adentrando agora na polêmica quanto aos direitos morais do autor da obra do Grafite, vejamos o artigo 24 da lei:

"Art. 24. São direitos morais do autor:

I - o de reivindicar, a qualquer tempo, a autoria da obra;

II - o de ter seu nome, pseudônimo ou sinal convencional indicado ou anunciado, como sendo o do autor, na utilização de sua obra;

III - o de conservar a obra inédita;

IV - o de assegurar a integridade da obra, opondo-se a quaisquer modificações ou à prática de atos que, de qualquer forma, possam prejudicá-la ou atingi-lo, como autor, em sua reputação ou honra;

$V$ - o de modificar a obra, antes ou depois de utilizada;

$V I$ - o de retirar de circulação a obra ou de suspender qualquer forma de utilização já autorizada, quando a circulação ou utilização implicarem afronta à sua reputação e imagem;

${ }^{18}$ BARBOSA, Denis Borges. "Direito Autoral e Liberdade de Expressão Estudos de Direito", 2005. P. 95. 
VII - o de ter acesso a exemplar único e raro da obra, quando se encontre legitimamente em poder de outrem, para o fim de, por meio de processo fotográfico ou assemelhado, ou audiovisual, preservar sua memória, de forma que cause o menor inconveniente possivel a seu detentor, que, em todo caso, será indenizado de qualquer dano ou prejuízo que lhe seja causado.

$\S 1^{o}$ Por morte do autor, transmitem-se a seus sucessores os direitos a que se referem os incisos I a IV.

$\S 2^{\circ}$ Compete ao Estado a defesa da integridade e autoria da obra caída em domínio público.

$\S 3^{\circ}$ Nos casos dos incisos V e VI, ressalvam-se as prévias indenizações a terceiros, quando couberem."

O inciso I do referido artigo faz-se aqui de grande importância para a análise das questões suscitadas quantos aos direitos morais do autor, eis que boa parte das lides tratam sobre a reinvidicação da autoria das obras, complementando com o inciso II, que faz referência direta aos nomes e pseudônimos dos artistas, algo que é fundamental na busca de identidade do grafiteiro ao comunicar-se com o cotidiano urbano, entendo por nome o qualquer forma de identificação do autor o legislado no artigo 12 da mesma lei ${ }^{19}$. Os dispositivos citados relacionam-se diretamente ao artigo 28 da mesma lei, qual seja:

"Art. 28. Cabe ao autor o direito exclusivo de utilizar, fruir e dispor da obra literária, artística ou científica."

Do enunciado extrai-se que o autor tem o legítimo direito exclusivo da reprodução de suas obras, cabendo a este provar no decurso do processo as alegações feitas quanto à utilização indevida em caso de não identificação de sua autoria.

O Capítulo V da lei de Direitos Autorais (artigos 46, 47 e 48) traz uma série de exceções quanto ao direito de reprodução de obras artísticas,

\footnotetext{
19 “Art. 12. Para se identificar como autor, poderá o criador da obra literária, artística ou científica usar de seu nome civil, completo ou abreviado até por suas iniciais, de pseudônimo ou qualquer outro sinal convencional."
} 
dispondo que não constitui ilicitude frente a este direito, ou seja, não é consumada ofensa ao direito do autor as circunstâncias descritas em um rol de exemplos possíveis. Vejamos o artigo 46:

"art. 46. Não constitui ofensa aos direitos autorais:

I - a reprodução:

a) na imprensa diária ou periódica, de notícia ou de artigo informativo, publicado em diários ou periódicos, com a menção do nome do autor, se assinados, e da publicação de onde foram transcritos;

b) em diários ou periódicos, de discursos pronunciados em reuniões públicas de qualquer natureza;

c) de retratos, ou de outra forma de representação da imagem, feitos sob encomenda, quando realizada pelo proprietário do objeto encomendado, não havendo a oposição da pessoa neles representada ou de seus herdeiros;

d) de obras literárias, artísticas ou científicas, para uso exclusivo de deficientes visuais, sempre que a reprodução, sem fins comerciais, seja feita mediante o sistema Braille ou outro procedimento em qualquer suporte para esses destinatários;

II - a reprodução, em um só exemplar de pequenos trechos, para uso privado do copista, desde que feita por este, sem intuito de lucro;

III - a citação em livros, jornais, revistas ou qualquer outro meio de comunicação, de passagens de qualquer obra, para fins de estudo, crítica ou polêmica, na medida justificada para o fim a atingir, indicando-se o nome do autor e a origem da obra;

IV - o apanhado de lições em estabelecimentos de ensino por aqueles a quem elas se dirigem, vedada sua publicação, integral ou parcial, sem autorização prévia e expressa de quem as ministrou;

V - a utilização de obras literárias, artísticas ou científicas, fonogramas e transmissão de rádio e televisão em estabelecimentos comerciais, exclusivamente para demonstração à clientela, desde que esses estabelecimentos comercializem os suportes ou equipamentos que permitam a sua utilização;

VI - a representação teatral e a execução musical, quando realizadas no recesso familiar ou, para fins exclusivamente didáticos, nos estabelecimentos de ensino, não havendo em qualquer caso intuito de lucro;

VII - a utilização de obras literárias, artísticas ou científicas para produzir prova judiciária ou administrativa;

VIII - a reprodução, em quaisquer obras, de pequenos trechos de obras preexistentes, de qualquer natureza, ou de obra integral, quando de artes plásticas, sempre 
que a reprodução em si não seja o objetivo principal da obra nova e que não prejudique a exploração normal da obra reproduzida nem cause um prejuízo injustificado aos legítimos interesses dos autores.

A ideia principal que se extrai da leitura deste artigo, focando em seu inciso V para a leitura da jurisprudência à frente, é que tece como fato diferenciador do que se vai dever, onerosamente ou não, por reprodução de obra artística, ou seja, aquele direitos morais positivados no artigo 26 e seus incisos do mesmo diploma, é o ânimo de lucrar a partir desta reprodução, não constituindo ilícito quanto ao uso acadêmico ou pessoal (ex: fotografia).

Entende Denis Barbosa sobre o referido artigo que "as limitações legais em matéria de propriedade intelectual - patentes, registro de cultivares, direitos autorais, etc. - representam uma conciliação entre interesses constitucionais fundamentais. De um lado, a esfera moral $e$ patrimonial da criação humana, protegida pelo texto básico; de outros, interesses tais como a tutela à educação, o direito de citação, o direito à informação, o cultivo das artes no ambiente doméstico, etc. Argumentar-seía, talvez, que tais limitações seriam tomadas sempre como exceções, a serem restritamente interpretadas. Mas exceções não são, e sim confrontos entre interesses de fundo constitucional."

Da forma tal qual foi exposta, as exceções ao Direito Autoral positivadas, expressamente, em um rol taxativo pelo artigo 46 da Lei de Direitos Autorais é um fenômeno advindo do princípio de proporcionalidade constitucional, buscando trazer equilíbrio entre os interesses privados do autor e o interesse público no ordenamento ${ }^{20}$, impedindo que o instituto do Direito Autoral seja algo absoluto diferenciando as hipóteses onde não foi o objetivo auferir lucro da utilização de obra científica, artística, literária que for.

\footnotetext{
${ }^{20}$ BARBOSA, Denis Borges. "Direito Autoral e Liberdade de Expressão Estudos de Direito", 2005. P.81
} 
Especificamente ao tratar de obras expostas em espaços públicos, a Lei de Direitos Autorais, mesmo que não tenha, propriamente, falado sobre o Grafite, traz em seus artigos 48, 77 e 78, lidos estes em conformidade, outras situações quanto ao direito de reprodução do autor:

“Art. 77. Salvo convenção em contrário, o autor de obra de arte plástica, ao alienar o objeto em que ela se materializa, transmite o direito de expô-la, mas não transmite ao adquirente o direito de reproduzi-la.

Art. 78. A autorização para reproduzir obra de arte plástica, por qualquer processo, deve se fazer por escrito e se presume onerosa."

Fato é que o Grafite é representado em logradouros públicos, eis que faz parte do seu "eu artístico" a comunicação com as dezenas de pessoas que percorrem os ambientes cinzentos das grandes metrópoles, alienando, o autor, a obra à intepretação do cenário urbano que faz-se de galeria para esta modalidade artística.

Utilizando-se da leitura sistemática da Lei dos Direitos Autorais, não podemos deixar de ver aqui uma clara limitação feita pelo artigo 77 ao artigo 48, eis que, apesar de ter. o autor, sua obra alienada em espaço público, não está presumida a alienação do direito à reprodução, que é exclusiva do artista autor, devendo a mesma ser feita mediante autorização deste, salvo as exceções feitas pelo artigo 46, ou seja, a obra é pública, porém tem autoria.

Neste sentido também vêm reproduzindo a jurisprudência à confirmar o direito do artista "grafiteiro" sobre o direito de reprodução de sua obra, mesmo que alienada em espaço público.

Discorrendo, agora, sobre o inciso IV, que trata sobre a integralidade da obra do grafite, a dificuldade presente neste encontra-se na própria natureza do grafite pois este dialoga diretamente com o meio urbano em que se encontra ao estar disposto em ambiente público e ao ar livre, sendo sujeito ao desgaste natural e a sobreposição por, também, outros grafiteiros, além de obras frutos de particulares ou entes públicos 
No que tange ao direito à integralidade da obra, enunciado semelhante se encontra na Convenção de Berna em seu artigo 6:

"independentemente dos direitos patrimoniais de autor, e mesmo depois da cessão dos citados direitos, o autor conserva o direito de reivindicar a paternidade da obra e de se opor a toda deformação, mutilação ou a qualquer dano à mesma obra, prejudiciais à sua honra ou à sua reputação"

No texto "Direito de Autor e Liberdade de Expressão", é suscitada uma dúvida quanto ao direito à honra do autor:

“Através do direito à integridade, repete-se no microssistema do direito autoral um problema largamente debatido entre constitucionalistas e civilistas: o conflito entre a liberdade de expressão e o direito à honra e à reputação. Considerando o caráter abstrato e de difícil comprovação característico das ofensas à honra, abre-se aqui espaço para toda sorte de abusos por parte dos autores na restrição ao uso de suas obras. „21

O trecho citado denuncia o desequilíbrio entre as pretensões do autor e de terceiros, pondo que o artigo, pode, por muitas vezes ser utilizado de forma, demasiadamente, autoritária ao defende-lo, porém há de se discordar no sentido de que o ordenamento do Direito Autoral encontra um rol taxativo extenso em seu artigo 46 quanto às exceções onde não cabe o direito do autor, encontrando equilíbrio no ordenamento, acarretando em uma leitura descontextualizada do que se entende por direito deste.

Explicando a importância do artigo, para o professor da Universidade Federal da Paraíba, Marcílio Toscano Franca Filho:

${ }^{21}$ https://www.maxwell.vrac.puc-rio.br/18997/18997_6.PDF 
"não é de hoje que se reconhece aos artistas em geral, sendo ou não proprietários da sua obra de arte, o direito moral (i.e. não necessariamente pecuniário ou patrimonial) à integridade física de sua produção artística, o que a doutrina francófona chama de "droit au respect" e os anglófonos denominam de "right of integrity". O núcleo essencial desse direito é preservar o próprio significado de uma obra de arte que, ao ser alterada em sua cor, tamanho, forma ou composição, pode vir a comprometer as intenções originais do seu autor, desrespeitando-o, desonrando-o ou comprometendo a sua reputação - mesmo depois que a obra tenha saído de suas mãos. ${ }^{22}$

Desprende-se daqui um viés ideológico e até "filosófico" da referida legislação: mais do que apenas defender o direito moral à imagem, ou seja, o valor pecuniário, devido ao autor, pela utilização da sua obra, a ideia original transcrita na obra, tal qual foi concebida, ou seja, sua "aura", ou sua "aparição única". ${ }^{23}$ Citando o trabalho, neste sentido, de Carla López Ullmann em "Liberdade de Acesso à Informação Versus Direitos Autorais Na Sociedade da Informação: A Responsabilidade Civil Por Reproduções na Internet” : “A bem entender de Sílvio Venosa, três são os requisitos fundamentais para que a criação intelectual seja abarcada pelo Direito Autoral, a saber: criatividade, originalidade e exteriorização. A criatividade decorre justamente do fato de que não há obra intelectual sem criação. Por outro lado, o segundo requisito - o da originalidade - quer dizer que a obra criada pelo autor não pode ser igual a qualquer outra

\footnotetext{
22 TOSCANO FRANCA FILHO, Maurício. O” GRAFITE E A PRESERVAÇÃO DE SUA INTEGRIDADE: A PELE DA CIDADE E O "DROIT AU RESPECT" NO DIREITO BRASILEIRO E COMPARADO". "Revista de Direito da Cidade", vol. 08, n 4, Página 8, ISSN 2317-7721.

23 "Para melhor compreender esse conceito de aura, concebido para objetos históricos, vamos ilustrá-lo com o conceito de aura para objetos naturais, definida como uma aparição única de algo distante, por mais próxima que esteja". BENJAMIN, Walter. "BENJAMIN E A OBRA DE ARTE". Cap.1 "A Obra de Arte na Era Da Sua Reprodutibilidade Técnica”. Página 16. Editora Contraponto, 1 edição, 2015.
} 
manifestação anterior. É dizer, a obra deve ser "integrada de componentes individualizadores, de tal sorte a não se confundir com outra preexistente. ${ }^{24}$

Desta forma e segundo a jurisprudência, como veremos em breve, a unicidade da obra é tutelada por lei e, inclusive, a obrigação do adquirente de não modificá-la, eis que é protegida da forma que "sai dos fornos" das mentes criativas do artista.

Alusão se faz a outro impasse no mesmo inciso, porém, neste ponto, questiona sobre uma própria deficiência do dispositivo citado da Lei dos Direitos autorais:

"O texto da norma brasileira é reconhecidamente comedido, falando apenas em "modificações" na obra de arte. A norma parece ser omissa quanto à destruição pura e simples de uma obra inteira e seu enquadramento caberia apenas nos atos que, de qualquer forma, possam prejudicar ou atingir o autor como tal, em sua reputação ou honra. São os aspectos pessoais que legitimam a proteção jurídica e o autor não poderá invocar aquela norma a não ser nos casos em que estiver em jogo sua reputação ou honra." 25

Discorrendo da crítica citada, discordo no sentido de que, qualquer modificação, sem a prévia autorização do autor, é uma destruição em si e, necessariamente atinge a honra deste como tal, eis que é fruto do dispêndio e criatividade do mesmo, porém mantém-se a mesma no sentido de que a letra da lei poderia prejudicar o direito subjetivo do autor pois trata da

\footnotetext{
${ }^{24}$ LÓPEZ ULLMANN, Carla. "LIBERDADE DE ACESSO À INFORMAÇÃO VERSUS DIREITOS AUTORAIS NA SOCIEDADE DA INFORMAÇÃO: A RESPONSABILIDADE CIVIL POR REPRODUÇÕES NA INTERNET" fIs. 5

${ }^{25}$ TOSCANO FRANCA FILHO, Maurício. O” GRAFITE E A PRESERVAÇÃO DE SUA INTEGRIDADE: A PELE DA CIDADE E O "DROIT AU RESPECT" NO DIREITO BRASILEIRO E COMPARADO”. Revista de Direito da Cidade, vol. 08, nº 4, Página 12.ISSN 2317-7721.
} 
modificação da mesma forma que a destruição total, devendo aqui buscarse uma interpretação mais extensiva e ativista no sentido de que se faça, pela ponderação, um estudo casuístico e proporcional quanto ao dano causado, não se fazendo, portanto, grandes "alardes" quanto à redação da norma, pois esta pode ser lida conforme almeja o autor, cabendo este dever à subsunção.

De qualquer forma, embora não seja este o caso, cita o ator jurisprudência para ser utilizada como analogia ao direito à integralidade da obra, qual seja:

"CIVIL. RESPONSABILIDADE CIVIL. DIREITOS AUTORAIS. RETIRADA DE ESCULTURAS CONFECCIONADAS SOB ENCOMENDA PARA ADORNAR AGÊNCIAS BANCÁRIAS. VIOLAÇÃO DA INTEGRIDADE FÍSICA DAS OBRAS. AUSÊNCIA DE PRÉVIA AUTORIZAÇÃO DO ARTISTA. VIOLAÇÃO DO DIREITO MORAL DO AUTOR. DANO. INDENIZAÇÃO. A propriedade intelectual não se transfere, de modo que a aquisição de original não confere ao adquirente os direitos patrimoniais de utilizar, fruir e dispor da obra, sem a prévia autorização do autor, nos moldes dos arts. 24, IV, 28 e 29, VIII e X, da Lei n. 9.610/98. A retirada das obras escultóricas, especialmente criadas para compor o projeto arquitetônico das agências bancárias da CEF, em São Leopoldo e Porto Alegre/RS, sem a prévia comunicação do artista, bem como a destruição de uma das esculturas, quando da sua retirada do espaço original, sem o seu prévio conhecimento, configuram a violação de direito moral do autor, implicando o ressarcimento pelos danos causados. A comprovação do nexo causal entre o ato culposo da CEF, bem como do abalo emocional sofrido pelo autor ensejam o pagamento de indenização por danos morais, conforme determina o art. 159 do Código Civil. Indenização fixada com base no abalo sofrido exclusivamente pelo autor, haja vista a ausência de provas conclusivas acerca da repercussão negativa na sua imagem junto ao meio artístico e comunidade em geral. Ônus 
sucumbenciais atribuídos à CEF, nos moldes do art. $20, \S 3^{\circ}$, do CPC. (TRF 4a. Região, Apelação Cível 199971000291870, Rel. Des. Fed. Edgard Antônio Lippmann Júnior, DJ 25/07/2001, p. 407) DIREITO AUTORAL. INDENIZAÇÃO. CONCURSO PARA CONFECÇÃO DE OBRA ARTÍSTICA. PAINEL DECORATIVO. REPRODUÇÃO PARCIAL EM LOCALIDADES NÃO PREVISTAS NO EDITAL. AUSÊNCIA DE CONSENTIMENTO. (...) DIREITOS MORAIS. INALIENABLIDADE E IRRENUNCIABILIDADE. LEI N. 9.610/98. (...)5. O Edital 02/2002 se destinou "a fixar normas para a realização do Concurso Público de Arte Plástica para a criação e execução de Mural decorativo, com as dimensões de 11,45m x 6,50m e área de 74,42 m², no Pavilhão de Aulas do Canela", de propriedade da UFBA. 6. Como se vê, o contrato não previu como modalidade de utilização a reprodução da obra do Autor, mesmo que em pequenas partes, em placas de sinalização para a circulação de pessoas em diversas dependências da UFBA. 7. A LDA ainda dispõe que: "Art. 24. São direitos morais do autor: I - o de reivindicar, a qualquer tempo, a autoria da obra; (...) III - o de conservar a obra inédita; IV - o de assegurar a integridade da obra, opondo-se a quaisquer modificações ou à prática de atos que, de qualquer forma, possam prejudicá-la ou atingi-lo, como autor, em sua reputação ou honra; (...) (TRF 1 ${ }^{\text {a }}$. Região, Apelação Cível AC 00251247220044013300, Rel. Des. Fed. João Batista Moreira, e-DJF1 13/08/2010, p. 177)"

Conforme elevação da jurisprudência do Grafite à qualquer obra artística ou intelectual pela analogia da Lei de Direitos Autorais para a sua proteção, o uso do art. 24, IV, tutela o mesmo como tal, pois a lei busca proteger os mesmos objetos, não podendo ser "separada por temas", ao menos até o momento que não houver um outro dispositivo legal específico neste sentido. 


\subsection{CASOS DE RELEVÂNCIA NA JURISPRUDÊNCIA}

A jurisprudência nacional, já há algum tempo, vem reconhecendo o grafite como obra artística e, consequentemente, sujeita à proteção da Lei de Direitos Autorais.

Sobre isto, afere-se que a temática ainda se encontra rasa pela escassez de doutrina extensiva sobre o fato, tendo o estudo presente focado no que vêm se discutido em sede de jurisprudência, o que agora será feito.

1. Analisando a apelação cível de número 013908490.2012.8.26.0100 cujas partes consistiam na Editora e Distribuidora Edipress LTDA (apelante) e Frederico George Barros Day (apelado), vemos um interessante impasse relacionado aos direitos morais e materiais do grafiteiro apelado com a sua obra.

Vejamos a ementa do caso citado:

“DIREITO AUTORAL. DIREITOS PATRIMONIAIS E MORAIS DE AUTOR. REPRODUÇÃO DE OBRA DO TIPO 'GRAFITE' EM FOTOGRAFIAS INSERIDAS EM MATÉRIA DE REVISTA AUTOMOBILÍSTICA EDITADA PELA RÉ. DIREITOS PATRIMONIAIS NÃO VULNERADOS. OBRA SITUADA PERMANENTEMENTE EM LOGRADOURO PÚBLICO, CUJA REPRODUÇÃO É LIVRE. INTELIGÊNCIA DO ART. 48 DA LEI 9.610/98. AUSÊNCIA, OUTROSSIM, DE INTUITO COMERCIAL DA REPRODUÇÃO, DADO O CARÁTER NITIDAMENTE JORNALÍSTICO DA MATÉRIA. DIREITOS MORAIS, POR OUTRO LADO, VIOLADOS. IMAGEM REPRODUZIDA DA OBRA QUE FOI MANIPULADA DIGITALMENTE, AO PONTO DE RESTAR DESCARACTERIZADA E DEFORMADA. MANUTENÇÃO DA INCOLUMIDADE DA OBRA OU, AO REVÉS, INTRODUÇÃO DE MODIFICAÇÃO SUPERVENIENTE QUE CONSISTEM EM PRERROGATIVAS PERSONALÍSSIMAS DO CRIADOR (ART. 24, IV E V, DA LEI 9.610/98). DANO 
MORAL CARACTERIZADO, NA HIPÓTESE, 'IN RE IPSA', MEDIANTE A PUBLICAÇÃO. RESPONSABILIDADE CIVIL DA RÉ CARACTERIZADA. 'QUANTUM' ARBITRADO COM RAZOABILIDADE, PELA SENTENÇA. AÇÃO PARCIALMENTE PROCEDENTE. SENTENÇA REFORMADA EM PARTE. RECURSO PARCIALMENTE PROVIDO."

A apelação citada buscava a reforma de decisão que confirmou, em

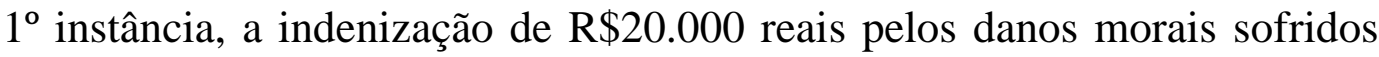
além de $\mathrm{R} \$ 3.000$ reais pelos danos materiais propostos pelo autor Frederico George Barros Day pela violação aos direitos de autor deste.

O fato objeto da demanda era a fotografia realizada de automóveis na região conhecida como "Beco do Batman" (citada no primeiro capítulo), onde foram comparados "versão clássica e atual de automóvel esportivo" e, ao fundo, compunha o cenário obra de autoria de Frederico George Barros Day (apelado).

A apelante alegou não ser possível o reconhecimento da obra da parte apelada, eis que não havia meios próprios para a identificação de tal, como assinatura ou nome do autor (artigo 12 da Lei de Direitos Autorais ${ }^{26}$ ), o que foi contestado pelo desembargador relator Vito Guglielme da $8^{\mathrm{a}}$ Vara Cível da Comarca de Santana, SP, pelos fundamentos de que havia ali presente "pássaro estilizado", marca de todas as obras, em analogia à assinatura, da parte apelada, reconhecendo a autoria positivada no artigo $7^{\circ}$ da Lei de Direitos Autorais ${ }^{27}$.

Dando parcial provimento ao recurso, reconhece o relator que, apesar de a apelante ser Sociedade Organizada voltada a aferição de lucro, a utilização da imagem configuraria mera peça jornalística e fazia apenas composição ao cenário comparativo das fotografias e não contribuiu para a

\footnotetext{
26 “Art. 12. Para se identificar como autor, poderá o criador da obra literária, artística ou científica usar de seu nome civil, completo ou abreviado até por suas iniciais, de pseudônimo ou qualquer outro sinal convencional."

27 "Art. $7^{\circ}$ São obras intelectuais protegidas as criações do espírito, expressas por qualquer meio ou fixadas em qualquer suporte, tangível ou intangível, conhecido ou que se invente no futuro, tais como: (...) VIII - as obras de desenho, pintura, gravura, escultura, litografia e arte cinética;"
} 
aferição do mesmo, não tendo fins publicitários, reformando a decisão em $1^{\text {a }}$ Instância que conferiu ao apelado os danos morais, não caracterizando as hipóteses dos artigos 77 e 78 da Lei de Direitos Autorais. ${ }^{28}$

Cita, o Relator, sobre ensinamento de Fábio Ulhôa Coelho para a fundamentação:

"Quando não se compatibilizam os interesses privados do autor, voltados ao monopólio na utilização de sua obra, e o interesse público referente à difusão do conhecimento, educação e cultura, este último tem, evidentemente, prevalência. São as hipóteses de licença legal, em que a obra pode ser utilizada sem a prévia e expressa autorização do titular do direito autoral e independentemente do pagamento de qualquer remuneração", 29

Quantos os direitos morais do autor, quais sejam os da violação ao direito de integralidade da obra legisladas pelo artigo 24 , incisos IV e $\mathrm{V}^{30}$, foram mantidos pelo relator, porque, além da utilização da obra de autoria do apelado, foram modificados digitalmente ao menos três do pontos comparados à original, corroborando para a deformação da mesma, afirmando que o direito aqui protegido é uma "projeção da personalidade do autor", não havendo o que reformar, confirmando, desta forma, o reconhecimento do uso do diploma dos direitos autorais como mecanismo adequado para apreciar as demandas relativas ao Grafite.

28 “Art. 77. Salvo convenção em contrário, o autor de obra de arte plástica, ao alienar o objeto em que ela se materializa, transmite o direito de expô-la, mas não transmite ao adquirente o direito de reproduzi-la. Art. 78. A autorização para reproduzir obra de arte plástica, por qualquer processo, deve se fazer por escrito e se presume onerosa."

29 ULHÔA, Fábio Coelho. in Curso de direito civil, v. 4, 4ª . ed., SãoPaulo, Saraiva, 2012)

30 Art. 24. São direitos morais do autor: (...) V - o de assegurar a integridade da obra, opondo-se a quaisquer modificações ou à prática de atos que, de qualquer forma, possam prejudicá-la ou atingi-lo, como autor, em sua reputação ou honra; V - o de modificar a obra, antes ou depois de utilizada, 
Nas palavras do relator:

"Se compete ao autor e apenas a ele modificar a criação quando the aprouver e, bem, vetar alterações com as quais não consinta, é certo que as modificações operadas pela apelante sobre a imagem da obra e que nem ela própria nega! se traduzem em ato ilícito que deu azo a prejuízo em desfavor do autor, configurando-se in re ipsa".

2. Versando também sobre os direitos materiais e morais do autor, o caso mais interessante encontrado e que também é uma verdadeira aula sobre arte urbana e como sua tutela deve ser compreendida no direito nacional, é a apelação de número 1007409-55.2015.8.26.0011 que, baseado no artigo 942 do CPC, ampliou-se a turma julgadora por divergência, designando-se Moreira Viegas, o segundo desembargador, como relator, ficando responsável pelo voto vencido o desembargador James Siano, relator sorteado, dando-se provimento ao recurso por maioria de quatro votos.

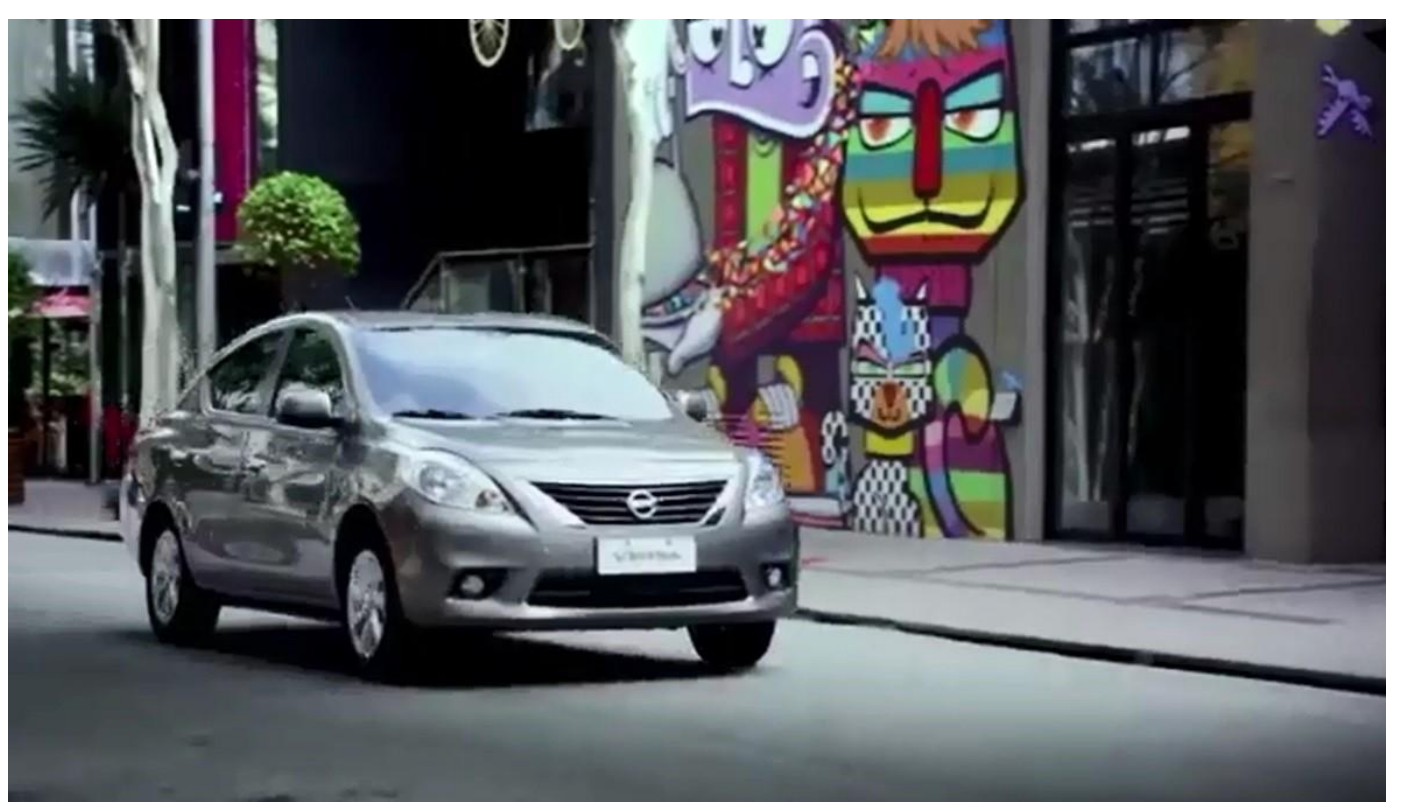

Figura 7

Vejamos a ementa do caso citado: 
"DIREITO AUTORAL INDENIZAÇÃO POR DANOS MATERIAIS E MORAIS - Improcedência - Obra realizada em logradouro público - Reprodução para fins de divulgação de automóvel da marca - Norma do artigo 48, da Lei no 9.610/98, que não afasta a responsabilidade pela reprodução indevida (para fins lucrativos ou comerciais) - Direito moral dos autores de terem seus nomes ou sinal indicado - Direito patrimonial que reside no fato de não ter sido consentida a divulgação de sua obra para fins comerciais Indenização devida Sentença reformada Recurso Provido."

O caso tem como partes os artistas Camila Pavanello e Alexandre Tadeu Alves como apelantes e Nissan do Brasil Automóveis LTDA, LEW'LARA/TBWA Publicidade Propaganda LTDA e Reccorte Produções de Vídeos e Filmes EIRELI - EPP como apelados. A Apelação buscava reformar sentença em $1^{\circ}$ instância que negou pedido de indenização por danos morais e materiais pedidos pelos autores.

$\mathrm{O}$ fato que originou a lide gira em torno de comercial feito pela Nissan em 2014 onde utiliza-se ao fundo grafites feitos pelos ora apelados, relacionando a necessidade de um veículo espaçoso com a vida urbana. Segundo à Revista Folha de São Paulo, Chevitz tentou sem sucesso um acordo extrajudicial com as partes apeladas, sem obter sucesso. ${ }^{31}$

Analisando-se o acórdão proferido em sede de $2^{\circ}$. Instância pela $5^{\mathrm{a}}$ Câmara de Direito Privado do Tribunal de Justiça de São Paulo, conforme aduz o $2^{\circ}$ relator Moreira Viegas de forma brilhante, chamando a atenção sobre a dificuldade que presta a arte urbana na discussão do que é público e privado:

"Se o espaço da arte foi, por excelência, o espaço privado (museus e galerias), a chamada arte urbana deslocou a arte para o

\footnotetext{
${ }^{31}$ https://www1.folha.uol.com.br/ilustrada/2017/11/1935197-artistas-podemser-indenizados-por-anuncio-de-carro-que-exibe-grafite.shtml
} 
espaço público. Os limites diluíram-se e o privado passou a encontrar-se no público e vice versa."

Continuando a leitura, é discutida a função social do grafite, reiterando o seu valor histórico cultural, como movimento de vozes que, antes apagadas pela discriminação, vão às ruas conquistar espaço e voz através dos muros da cidade, tendo conquistado, desde a década de 70 o reconhecimento do status de arte. Conforme enuncia o magistrado:

"Não podemos mais negar que o artista saiu às ruas, mas não só ele. A sociedade também se mobilizou para reivindicar seus direitos ocupando ruas, praças e avenidas, com inabalável conotação política. $O$ ativismo surge na arte e reverbera na vida política. A arte tornou-se ativista e os muros tornaram-se páginas a serem escritas, como alternativa contra a censura e a opressão. É no locus urbano que o artista se expõe e busca ser "ouvido" em suas inquietações, interpretações e protestos de cunho sociais elou políticos."

Justifica, assim, a tutela do grafite, conforme as cortes, inclusive citando a norte americana como uma das pioneiras, como sendo o caminho natural apresentada por uma nova realidade que não pode ser negada.

Argumenta ainda que o disposto no artigo 48 da Lei de Direitos Autorais, ou seja, o fato de as obras encontrarem-se expostas em logradouros públicos, autoriza a sua livre reprodução, porém não tira a responsabilidade dos apelados de identificar e remunerar os autores pelo seu direito exclusivo de reprodução, eis que, a hipótese em voga não se encontra nas exceções aos direitos autorais dispostas no artigo 46 do mesmo diploma, eis que há na propaganda a intenção direta de auferir lucro e o grafite funciona aqui como fator valorativo do vídeo realizado, ou seja, compõe o fim publicitário deste. 
Ainda afirma, retoricamente:

"Se os graffitis não agregassem valor ao material publicitário e, consequentemente, ao produto por ele lançado ao mercado, como alegam as rés, não teriam elas elegido justamente o local onde se situam as obras artísticas para servirem de pano de fundo do filme de divulgação do novo automóvel da Nissan.”

No vídeo publicitário de produto da Nissan, o cenário onde o grafite aparece corresponde à aproximadamente 4 dos 30 segundos que contém no mesmo, conforme argumentos utilizados pelas partes apeladas para negar o uso indevido dos direitos de reprodução, identificação e imagem dos autores grafiteiros, porém sobre o mesmo: "O que realmente importa é o destaque dado ao painel de autoria dos ora apelantes e idéia de modernidade rebeldia que deles se extrai e se pretende agregar ao novo produto."

Atacando outro ponto da defesa dos apelados, onde-se afirma que as obras objetos da lide estariam alienadas ao município ou ao proprietário(s) do imóvel, não se presume de domínio público, sendo devida a autorização prévia do artista autor e podendo ser onerosa, quando é constatada a "auferição de lucro", como é o caso em questão.

Ao tratar da necessidade da conjugação do artigo 48 com os artigos 77 e 78 da Lei de Direitos Autorais, cita precedente da $4^{\mathrm{a}}$ Turma do STJ para sustentar sua posição, onde se julgou o REsp. de número 951.521/MA, de relatoria do Ministro Aldir Passarinho Junior em 2011, decidindo:

“À toda evidência, a mera reprodução por fotografia de uma obra exposta em logradouro não configura ilicitude. A aludida norma legal dá essa liberdade, bem como a sua representação por outros meios. Porém, 
o sentido da liberdade há que ser conjugado com os direitos assegurados nos arts. 77 e 78 do mesmo diploma, que versam sobre a utilização daobra, portanto o seu proveito de ordem econômica, como geradora de renda para terceiros, alheios à sua confecção. Se o intuito é comercial direta ou indiretamente, a hipótese não é a do art. 48, mas ados arts. 77 e 78. Destarte, no momento em que a foto serve à ilustração de produto comercializado por terceiro para obtenção de lucro e sem a devida autorização, passa-se a ofender o direito autoral do artista, agravado, na espécie, pelo fato de não ter havido sequer alusão ao seu nome. Anoto que ainda poderia haver tolerância em relação a certas situações, como veiculação de propaganda turística, cultural e, outras do gênero, posto que inerente à atividade essencial à reprodução de paisagens, logradouros e outros bens públicos. Mas não são esses o caso dos autos. Importante, ainda, para a elucidação da presente demanda a distinção entre' logradouro público 'e 'domínio público', isto porque as referidas condições não resultam em igualdade de tratamento. A obra de arte colocada em logradouro público, embora seja um patrimônio público, gera direitos morais e materiais para o seu autor. (...) O certo é que a reprodução fotográfica das esculturas do autor embelezaram o produto da ré, sem qualquer contrapartida econômica para o artista, que vive dos frutos do seu trabalho."

Por todo o exposto, julga, então, procedente os pedidos de danos morais e materiais pelo uso indevido do direito de reprodução do autor, firmando aquele em $\mathrm{R} \$ 30.000,00$ e este em $\mathrm{R} \$ 5.000,00$.

O processo hoje encontra-se em sede Recurso Especial no STJ.

Dos casos apresentados e, principalmente, o último, depreende-se da importância de mais discussões sobre o assunto, sendo tema de extrema relevância quando a discussão acerca dos direitos autorais porque é visível, literalmente, a presença do grafite em nosso cotidiano urbano e, apesar de a jurisprudência estar indo em um sentido progressista quanto ao 
reconhecimento do Grafite como arte, dando tratamento a este, para todas as hipóteses o disposto na Lei de Direitos Autorais, há evidente crueza ainda sobre o tema e as consequências disto como tal.

Para o professor de Direito Urbanístico em Arquitetura e Urbanismo da FCT/Unesp, José Roberto Fernandes Castilho, o precedente desta decisão cria uma jurisprudência perigosa:

“A matéria é polêmica (o que se demonstra no voto divergente) mas, em linha de princípio, deve-se entender que a representação da via, sem o destaque de nenhuma edificação, é livre e não pode sofrer nenhuma restrição. A cidade é, por definição, obra comum, múltipla, plural; mas, de outro lado, seus edifícios, individualmente considerados, podem constituir obras protegidas. Portanto, se se pretender representar apenas certa $e$ específica edificação - por exemplo o Hotel Unique, projeto de Ruy Ohtake -, mostra-se inequívoca a incidência dos direitos autorais. São as circunstâncias do caso concreto que dirão se houve ou não representação indevida de obra protegida. Como registrado no acórdão do caso Nissan, "embora as obras produzidas pelos autores se encontrem em logradouro público, a autorização para reprodução não se presume, ainda mais quando há proveito econômico por quem as utilizou sem a prévia autorização e sem o retorno financeiro aos autores ", ,32

De fato, a matéria é polêmica, daí que advém a ideia defendida de que faltam mais estudos sobre o tema. Porém o reconhecimento do "direito de autor" ao artista grafiteiro, entendendo este como a parte mais fraca da relação referentes as lide de direitos autorais, onde aufere-se lucro com a reprodução de suas sobras sem consentimento e identificação, com o enunciado da história do Grafite que é uma história de marginalização e reconhecimento e notoriedade, representa, este caminho, um progresso

${ }^{32}$ http://vitruvius.com.br/revistas/read/drops/18.126/6925 
importantíssimo da modalidade artística, não prosperando, pelos termos da pesquisa feita, tal posição.

O caso a citar-se, apesar de não fundamentar-se nos Direitos Autorais, teve bastante repercussão nacional e, representando uma grave violação e uma importante jurisprudência sobre o assunto, merece aqui destaque.

3.Durante o seu mandato na Prefeitura de São Paulo, Doria, agora governador do estado de São Paulo, se afirmou como combatente às pixações na cidade afirmando sobre os grafites da cidade que "Os demais já estão envelhecidos, ou estão infelizmente mutilados por pichadores, esses serão pintados". 33

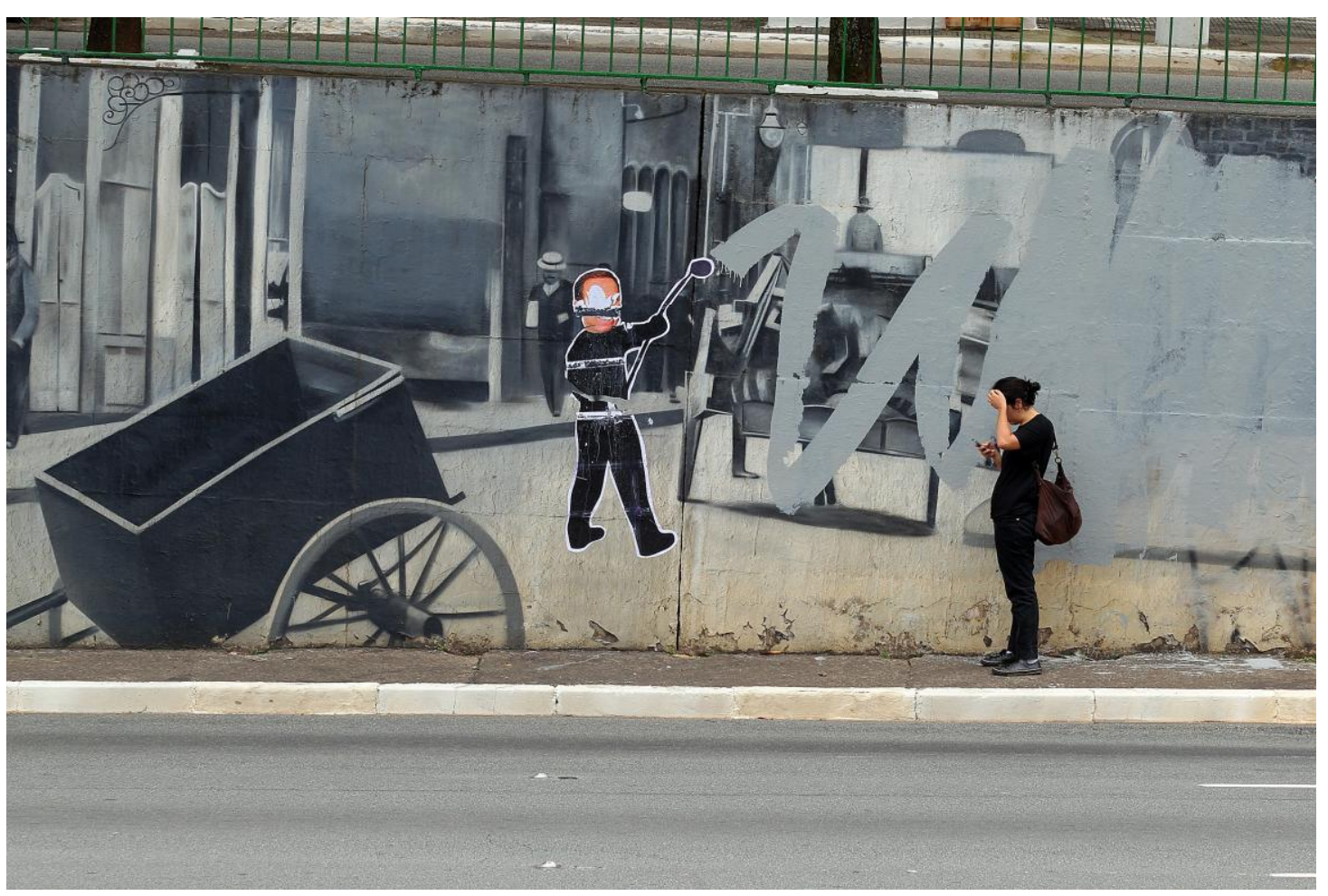

Figura 8

Como consequência da postura de Doria à frente da prefeitura de São Paulo, foi proposta Ação Popular de número 100453330.2017.8.26.0053 de autoria de Allen Ferraudo, Luiz Rogério da Silva,

\footnotetext{
${ }^{33} \mathrm{https} / / / \mathrm{g} 1$.globo.com/sao-paulo/noticia/avenida-23-de-maio-tera-oito-espacospara-grafites-e-desenhos-velhos-serao-apagados-diz-doria.ghtml
} 
Marcelo Ferraro, Paulo Abreu Leme Filho e Renata Vieira Silva e Sousa contra o Município de São Paulo e o próprio Dória.

No caso, cujo objeto foi a remoção do mural de Grafite da Avenida 23 de Maio, cuja confecção foi feita por mais de 200 grafiteiros, inclusive o do artista Kobra, condenou-se a Prefeitura de São Paulo assim como o, na época, prefeito, João Dória pelo dano causado ao Patrimônio artístico municipal no valor de $\mathrm{R} \$ 782.200,00$ reais, revestidos estes ao Fundo de Proteção do Patrimônio Cultural e Ambiental Paulistano (Funcap).

Além da demanda por indenização por lesão ao patrimônio artístico cultural reconhecida, também o foi a competência constitucional e legal do Conpresp - Conselho Municipal de Preservação do Patrimônio Histórico, Cultural e Ambiental de São Paulo na formulação de diretrizes de conservação e preservação do grafite na capital paulista, assim como a omissão do órgão por não ter cumprido tal função à época da execução do projeto municipal "Cidade Linda", responsável pela remoção dos grafites .

O juiz da $12^{\mathrm{a}}$ Vara de Fazenda Pública do Estado de São Paulo, Adriano Marcos Loroca, em decisão histórica, comparou o Grafite, marca histórica da cidade de São Paulo à patrimônio cultural imaterial, não fazendo diferenciação entre os mesmos: "Jamais houve determinação judicial para que se protegesse este ou aquele graffiti, ou todos, e sim a manifestação ou expressão cultural, portadora de referência à identidade e à ação de um grupo social da Capital, como bem cultural imaterial."

A fundamentar a decisão, é feita uma defesa aos artigos 215 e 216-A da Constituição Federal $^{34}$, alegando a violação à princípios fundamentais de participação da vida e da diversidade cultural que, no caso do grafite, suas telas se encontram no "espaço comum".

\footnotetext{
${ }^{34}$ Art. 215. O Estado garantirá a todos o pleno exercício dos direitos culturais e acesso às fontes da cultura nacional, e apoiará e incentivará a valorização e a difusão das manifestações culturais.(...) Art. 216-A. O Sistema Nacional de Cultura, organizado em regime de colaboração, de forma descentralizada e participativa, institui um processo de gestão e promoção conjunta de políticas públicas de cultura, democráticas e permanentes, pactuadas entre os entes da Federação e a sociedade, tendo por objetivo promover o desenvolvimento humano, social e econômico com pleno exercício dos direitos culturais
} 
Conforme dito, faz uma defesa à arte urbana, fazendo analogia à postura da prefeitura como lesiva a uma identidade cultural, qual seja a da arte urbana, reiterando que o grafite não é algo efêmero, sendo assim apenas a sua forma de expressão, porém é uma tradução de valores e práticas de uma cultura que encontra nas ruas a sua forma de expressão.

Segundo o juiz:

"Patrimônio cultural como processo, dinâmico, e não como produto,tangível. Conservam-se assim os valores de identidade de um grupo social, a suamanifestação cultural, que, no caso, denomina-se de arte urbana. Entrelaçamento desta comoutras manifestações artísticas e culturais é evidente (Hip-hop, Rap, Skate, entre outras). A arte urbana é parte da "cultura de rua"”,

O município de São Paulo sustentou que o CONPRESP teria competência apenas para a atribuição de "fixar diretrizes à política de conservação de patrimônio histórico e cultural, cujos bens possam ser objeto de tombamento" sendo o grafite algo efêmero, não comportando a proteção deste. Contestado pelo referido juiz, é ressaltado que a necessidade de proteger o grafite é a mesma de qualquer arte porque este também o é, reconhecidamente, portanto, patrimônio histórico e cultural, como o citado, impedindo, desta forma, que venha, futuramente, ocorrer novamente algo semelhante.

\subsection{DIÁLOGO COM O DIREITO COMPARADO}

Nos Estados Unidos está em vigor o United States Copyright Law que confere ao autor o poder de exclusividade ou "propriedade sobre sua obra. $^{35}$

Quando a tutela relativa ao Grafite, deve atender a dois critérios:

. Deve ser aferida a originalidade da obra;

\footnotetext{
${ }^{35}$ BARBOSA, Denis Borges. "Direito Autoral e Liberdade de Expressão Estudos de Direito”, 2005. Pág. 169
} 
. Necessita-se que esteja em um meio tangível ${ }^{36}$

Citando Keith Haring, a autora chama a atenção para o estiolo particular do mesmo, qual seja as "pessoas dançantes desenhadas de forma característica nos desenhos de Haring", fixadas em paredes do metrô, sendo, portanto, possível aferir a originalidade e e averiguação de meio tangível no exemplo. ${ }^{37}$

Diferentemente do nosso ordenamento, que difere o grafite da "pixação", sendo este crime positivado pela Lei de Crimes Ambientais, que falaremos em breve, alerta a autora que o os "tags" (assinaturas), análogos à nossa "pixação", não são protegidos pelo "copyright”, sendo estes muito simples para serem considerados obras de arte.

O que se protege no copyright é a obra intelectual, podendo ser objeto de proteção desta mesmo quando, posteriormente, é destruído, o que se difere da merda efemeridade, onde não cabe a proteção.38

\footnotetext{
36 "In order to receive protection under copyright, an artistic expression must comply with the following minimum legal requirements: it must be a work of authorship that is original and fixed in any tangible medium of expression." LERMAN, Celia. "PROTECTING ARTISTIC VANDALISM: GRAFFITI AND COPYRIGHT LAW", "N.Y.U. JOURNAL OF INTELL. PROP. \& ENT. LAW". Vol.2:295. Fls. 307, 308 ${ }^{37}$ Ibidem, p. 308.

${ }^{38}$ Ibidem, p. 309
} 


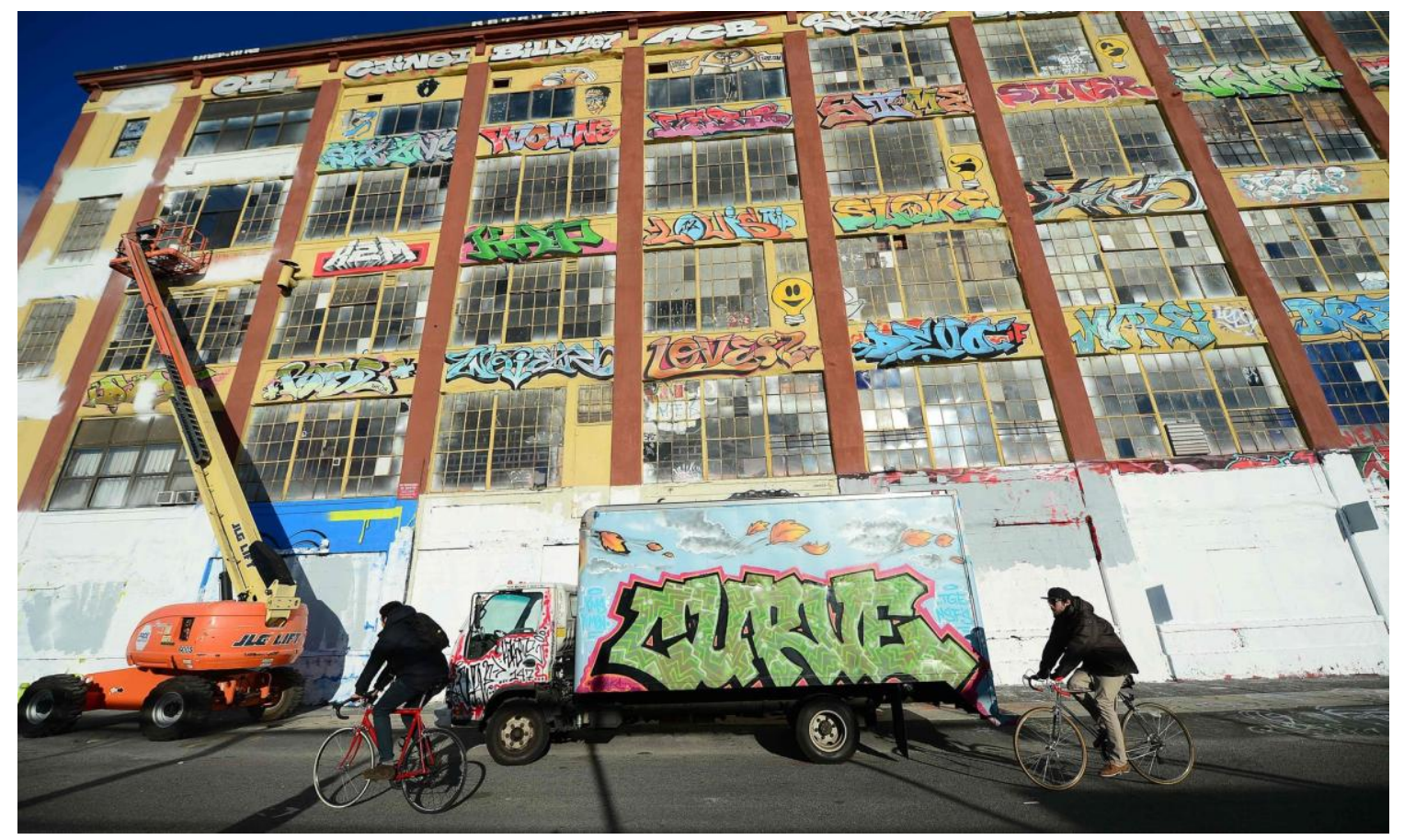

Figura 9

Caso ocorrido em 2013 onde Jerry Wolkoff, proprietário da G\&M Realty, "antiga fábrica com $18.500 \mathrm{~m}^{2}$ ", objetivando a construção de condomínios de luxo, buscava a destruição do edifício, localizado no complexo conhecido como "5Pointz", área ocupada pelos famosos grafites de Nova Iorque.

Wolkoff, então, evitando a notoriedade dos grafites em eventual destruição do edifício, ordenou que fossem pintadas todas as paredes do edifício, destruindo as artes ali imortalizadas por tantos grafiteiros de tantas partes do mundo e, ironicamente, foi o mesmo que deu autorização a estes, no ano de 1993 para a realização do feito no local onde era considerado a "primeira mecca do grafite do mundo", sendo o maior espaço legal para a confecção do mesmo em todo o território americano.

Apesar da destruição permanente de patrimônio cultural da humanidade pela importância das obras que ali estavam pintadas sob as paredes do edifício, o empresário foi condenado pela Corte de Nova Iorque em um júri civil no ano de 2017, em ação movida pelos grafiteiros por ter violado a Lei de Direitos dos Artistas Visuais em 45 casos, sendo 
confirmada a decisão pelo juiz Block na quantia de US\$ 6,7 milhões de dólares.

À época Johanatan Baum, representante do coletivo de grafiteiros e responsável pela curadoria do local, apesar da completa destruição, que não poderá ser desfeita, comemorou o precedente: "A decisão deixa claro que o grafite está na mesma categoria que qualquer outra bela arte, tendo o mesmo grau de proteção da lei federal. Por mais que a obra do 5Pointz tenha sido apagada, seu legado resiste ${ }^{39 ",}$

Caso de bastante repercussão porque, mesmo em um dos países e cidades com os jugados mais antigo e progressistas a favor dos direitos autorais e preservação do Grafitti, não foi suficiente para protege-lo antes de sua total destruição.

\section{CAPÍTULO III - GRAFITE VS. PIXAÇÃO}

\subsection{DOS CONCEITOS POSITIVADOS NA LEI DE CRIMES}

\section{AMBIENTAIS}

A lei de crimes ambientais brasileira (Lei 9.605/98) traz em sua redação original do artigo 65 a seguinte definição:

“Art. 65. Pichar, grafitar ou por outro meio conspurcar edificação ou monumento urbano: Pena - detenção, de três meses a um ano, e multa."

Tal lei, que antes criminalizava tanto o grafite quanto a "pixação", utilizando-se da forma escrita popular entre os "pixadores" 40 , foi alterada apenas em 2011 pela lei 12.408, onde se descriminalizou apenas o grafite.

Vejamos a sua redação atual:

\footnotetext{
39 https://oglobo.globo.com/cultura/artes-visuais/tribunal-de-ny-condenaempresario-pagar-us-67-milhoes-artistas-por-grafites-apagados-22397394

${ }^{40}$ Sobre o termo e o tema, é importantíssimo o destaque para o documentário “PIXO” de direção de João Wainer, 2017, disponível em https://www.youtube.com/watch?v=skGyFowTzew
} 
“Art. 65. Pichar ou por outro meio conspurcar edificação ou monumento urbano.

Pena - detenção, de 3 (três) meses a 1 (um) ano, e multa.

$\S 1^{\underline{0}}$ Se o ato for realizado em monumento ou coisa tombada em virtude do seu valor artístico, arqueológico ou histórico, a pena é de 6 (seis) meses a 1 (um) ano de detenção e multa.

$\S 2^{-}$Não constitui crime a prática de grafite realizada com o objetivo de valorizar o patrimônio público ou privado mediante manifestação artística, desde que consentida pelo proprietário e, quando couber, pelo locatário ou arrendatário do bem privado e, no caso de bem público, com a autorização do órgão competente e a observância das posturas municipais e das normas editadas pelos órgãos governamentais responsáveis pela preservação e conservação do patrimônio histórico e artístico nacional."

Nas palavras do juiz da $12^{\mathrm{a}}$ Vara de Fazenda Pública do Estado de São Paulo, Adriano Marcos Loroca, no processo de número 1004533 30.2017.8.26.0053, já citado aqui anteriormente:

"De toda forma, caberá ao CONPRESP definir diretrizes que preservem essebem cultural, face à sua intervenção necessária na paisagem urbana, sem antes classificar o que pode ser consideradograffiti,em contraponto à "pixação", distinção tipicamentepaulistana, e a outras manifestações, comotags e "gra-pixo" ou bomber (AlexandreBarbosa Pereira,in Um rolê pela cidade de riscos, leituras da pichação em São Paulo,Editora Edfuscar, pp. 40/41). Aliás, essa separação, que não ocorre nos EUA, cujograffitiserviu de inspiração, revela o caráter antropofágico da nossa” cultura.

O juiz, ao embasar sua decisão, argumentando, não se esquiva de tecer uma crítica ácida à legislação ambiental presente que opta por criminalizar a "pixação" em detrimento do grafite, objeto de confusão que trouxe as consequências da política de "Cidade Limpa" de autoria de, na época prefeito, João Dória. 
O fato é que, pela redação da norma, problemática foi criada após a descriminilização do grafite, qual seja, a zona de penumbra que envolve o que é "pixação" e o que é grafite, deixando nas mãos do magistrado a subjetividade para decidir no caso concreto se uma lide envolve direitos autorais ou o crime positivado na lei de crimes ambientais, por exemplo.

Reconhecendo que a descriminilização do grafite foi algo fruto de uma conquista histórica exemplar por voz e liberdade de expressão numa sociedade segregadora e este fato culmina com o processo de reconhecimento de tal como arte, sendo tratada para todos os feitos legais como a mesma, quando se discute, em termos gerais, "pixação" e grafite, estamos aqui discutindo o conceito de "arte", entendendo aquela como não adequada ao termo em detrimento desta.

Conforme foi explanado no capítulo I do presente estudo, este conceito se insere numa dinâmica de não exatidão de tamanha grandeza que nem estudiosos de todas as formas de arte e linhas de pesquisa conseguem uma definição própria do que consistiria os seus conceitos, mudando na história conforme quem tem hegemonia de poder, além de ter assimilações diferentes nas mais diversas culturas possíveis. Deste entendimento, destacamos que nem na hipótese do magistrado ser especialista formado em artes, poderia elucidar como verdade absoluta um conceito próprio para a "arte", da forma que se cobra do mesmo.

$\mathrm{Na}$ visão de Anne Cauquelin quanto a um conceito pragmático da arte:

“Ao propor que se entenda por "teorias da arte” qualquer discurso cujos efeitos sobre o domínio artístico podem ser notados, estaremos abrindo à teoria um alcance mais vasto do que aquele que em geral the é consignado. E, se aceitarmos essa definição absolutamente pragmática (as teorias julgadas de acordo com seus efeitos), ela nos conduzirá então a caracterizar- a “tipologizar”- um leque de ações possíveis, e de fato levadas a cabo, no que diz respeito à constituição e 
depois à manutenção ou à transformação do sítio da arte, de seus princípios, até mesmo de suas regras, Em suma, ela nos conduziria a analisar tipos de ação, em vez de avaliar o conteúdo conceitual das especulações. A partir de um inventário de ações possíveis, poderíamos então determinar um lugar para cada teoria, bem como para cada tentativa de teorização. ${ }^{41}$

É notável um certo fetichismo de tipologizar conceitos vindos do direito, até pela justificativa questionável do que seria "segurança jurídica", porém ao fazê-lo com as artes, pela construção jurisprudencial porque, pela redação do artigo 65 da Lei de Crimes Ambientais assim será feita, incorre o magistrado em solucionar uma área de dissenso desde Platão até a atualidade, o que é clarividente e extremamente questionável quanto à competência para tal.

Analisemos agora outra problemática que flutua num mar de problemas possíveis advindos da referida norma, qual seja o seu parágrafo segundo:

(...) $\S 2^{\underline{o}}$ Não constitui crime a prática de grafite realizada com o objetivo de valorizar o patrimônio público ou privado mediante manifestação artística, desde que consentida pelo proprietário e, quando couber, pelo locatário ou arrendatário do bem privado e, no caso de bem público, com a autorização do órgão competente e a observância das posturas municipais e das normas editadas pelos órgãos governamentais responsáveis pela preservação e conservação do patrimônio histórico e artístico nacional."

Da redação da norma, constatamos uma nova criação legislativa, qual seja o grafite lícito e o ilícito. Se formos analisar boa parte dos grafites que ganharam notoriedade histórica ao longo do tempo, veríamos que eles

${ }^{41}$ CAUQUELIN, Anne. "TEORIAS DA ARTE”. TODAS AS ARTES, 1ạ. Edição, 2005.

Págs 16 e 17. 
nasceram da ilicitude, perante tal proposta legislada, eis que é da natureza da tal forma de arte, desde a sua origem, a contestação do status quo econômico-social feito pelos grupos que se sentiram marginalizados

O Código Civil, vigente desde 2002, trata, especificamente, sobre as condutas ilícitas, a extensão e responsabilidade destas. Sérgio Cavaliere Filho explicita com clareza, ao citar outros autores, a dificuldade do uso do termo.

"Todas as definições dadas ao ato ilícito, sobretudo entre os clássicos, seguem essa mesma linha - íntima ligação entre o seu conceito e o de culpa. Tal critério, entretanto, cria enorme dificuldade em sede de responsabilidade objetiva, na qual não se cogita culpa” (Cavaliere Filho, Sérgio)

Sobre o seu aspecto objetivo:

"No seu aspecto objetivo, leva-se em conta para a configuração da ilicitude apenas a conduta ou o fato em si mesmo, sua materialidade ou exterioridade, e verifica-se a desconformidade dela com a que o Direito queria. A conduta contrária à norma jurídica, só por si, merece a qualificação de ilícita ainda que não tenha origem numa vontade consciente e livre (...) A contrariedade a direito é condição objetiva que se configura por ter sido violada a ordem jurídica"

Sobre o aspecto subjetivo:

"A qualificação de uma conduta como ilícita implica fazer um juízo de valor a seu respeito - o que só é possível se tal conduta resultar do ato humano consciente e livre. Por esse enfoque subjetivista, a ilicitude só 
atinge sua plenitude quando a conduta contrária ao valor que a norma visa a atingir (ilicitude objetiva) decorre da vontade do agente; ou, em outras palavras, quando o comportamento objetivamente ilícito for também culposo.

Assim, conclui sobre o tema:

"A violação de um dever jurídico possibilita formular, a seu respeito, dois juízos de valor: o juízo de valor sobre o caráter anti-social ou socialmente nocivo do ato ou do seu resultado e o juízo sobre a conduta do agente, na sua dimensão ético jurídica."

Vejamos agora os artigos que tratam das condutas e omissões que podem gerar dano material ou moral a outrem, quais sejam os atos ilícitos, dispostos nos artigos 186, 927 e 944 do diploma citado:

“(...) Art. 186. Aquele que, por ação ou omissão voluntária, negligência ou imprudência, violar direito e causar dano a outrem, ainda que exclusivamente moral, comete ato ilícito

(...)Parágrafo único. Haverá obrigação de reparar o dano, independentemente de culpa, nos casos especificados em lei, ou quando a atividade normalmente desenvolvida pelo autor do dano implicar, por sua natureza, risco para os direitos de outrem

Art. 927. Aquele que, por ato ilícito (arts. 186 e 187), causar dano a outrem, fica obrigado a repará-lo.

(...)

Art. 944. A indenização mede-se pela extensão do dano.

O que se discute aqui, agora, é o direito à propriedade, positivada no caput do artigo 5 da Constituição Federal, qual seja:

(...) Art. $5^{\mathbf{o}}$ Todos são iguais perante a lei, sem distinção de qualquer natureza, garantindo-se aos brasileiros e aos estrangeiros residentes no País 
a inviolabilidade do direito à vida, à liberdade, à igualdade, à segurança e à propriedade $(. .$.

É de amplo conhecimento que o Graffiti se utiliza da paisagem urbana, incluindo-se aqui a propriedade privada, que compõe tal cenário, criando, assim um conflito.

Como tudo em direito, logicamente, o dano deve ser comprovado, não bastando a mera alegação de dano material ou moral para provar o fato alegado ato ilícito, ou seja, o ato contrário ao ordenamento jurídico, positivado no artigo 180, interpretando o dever de reparo ao dano do artigo 927 nos limites do artigo 944, qual seja o princípio da equidade, averiguando-se aqui a extensão do dano causado, não podendo ser perceptível dano quando há valorização do imóvel, ou cai o ordenamento às gargalhadas de um conservadorismo que não vai à lugar nenhum.

\section{CONCLUSÃO IV}

\subsection{DO FUTURO DA TUTELA DO GRAFITE}

O direito e o Grafite, findando este esforço, é, no horizonte apresentado, ainda um tema extremamente recente e disto se averigua a ausência de estudos fundos sobre o referido.

É averiguado na jurisprudência nacional um movimento de crescente reconhecimento do grafite como arte, tal qual é, em represália aos atores que trabalham para não dar voz a cultura da arte urbana, o que é recebido com extremo prazer. Porém e, talvez até faça parte da dinâmica de constante protesto, mesmo em cidades onde o tema é tratado desde os anos 70 com a seriedade que merece, vemos a ação ainda de particulares para a destruição do mesmo, mostrando, ainda sua sensibilidade, mesmo sendo coibida pelo judiciário. 
O fato revela que a nossa curta experiência com a dinâmica ainda vai passar por longas jornadas até se alcançar entendimento mais apurado sobre a dinâmica que ronda a referida arte.

Erra aqui a Lei de Crimes Ambientais em deixar nas mãos do magistrado o poder de definir o que é arte ou não, sendo algo absolutamente, abstrato em suas mais diversas linhas de pensamento.

Nas palavras de Carolina Matozzo:

“(...) Os lazeres artísticos são aqueles que estão ligados à arte, à busca pelo belo, o imaginário, ao consumo do resultado das produções artísticas e à criação não profissional. O teatro, a música, o cinema, a dança, as artes plásticas, a poesia e a ficção estão entre as atividades em que predomina o interesse artístico. É aí que o lazer se encontra com a cultura." 42

Citando Milton Campos, continua a autora:

Milton Santos afirmou que o espaço construído, embora seja em tese comum, é usado de forma seletiva, reservada àqueles que dispõem de capital financeiro. Esse espaço é arranjado em consonância com os interesses das grandes empresas no desenvolvimento econômico, tendo o crescimento capitalista um elemento indispensável à sua manutenção na organização daquele. Assim, o espaço é manipulado para aprofundar as diferenças entre classes, refletindo a divisão do trabalho177. Os progressos técnicos, de aperfeiçoamento das comunicações e das tecnologias, não são desfrutados por todos equitativamente. O acesso livre à cidade é privilégio de poucos. As diferenças na organização do espaço

\footnotetext{
42 MATTOSO LOPES, Ana Carolina. "O Direito Social ao Lazer em Perspectiva Crítica: Desigualdades e democratização do Acesso", 2017.Pág. 42
} 
são um dos grandes elementos da desigualdade social. Elas, ao mesmo tempo que a refletem, a reforçam. ${ }^{43}$

A partir do extraído, é fato de que o Grafite saiu das ruas e entrou nas galerias de arte, sendo apreciado e defendido como tal, em detrimento da "pixação" que ainda constitui crime, crítica que também fazem os "pixadores" quanto à "gourmetização" do grafite, pela ainda presente marginalização da prática.

Tanto o grafite quanto a "pixação" tem uma origem comum, apesar de aquele ter se transmutado, em termos com o tempo devido ao seu próprio reconhecimento como manifestação artística-cultural, o que, na prática, denuncia uma desigualdade social endêmica dos centros urbanos.

Talvez este seja o objetivo de deixar "pixo" ainda ser crime.

\section{REFERÊNCIAS BIBLIOGRÁFICAS}

.SHINER, Larry. "La Invención del Arte”, Editora Paidós Estética, 2001. .BELTING, Hans "A Arte Universal e Minhorias: Uma Nova Geografia da História da Arte" fls. 96

. COUTINHO BISSOLI, Daniela. "GRAFFITI: PAISAGEM URBANA MARGINAL A INSERÇÃO DO GRAFFITI NA PAISAGEM URBANA DE VITÓRIA (ES)" 2011.

. http://www.eduardokobra.com/biografia/

. https://super.abril.com.br/blog/oraculo/por-que-o-beco-do-batman-emsao-paulo-tem-esse-nome/

. http://streetartrio.com.br/o-projeto/

. BARBOSA, Denis Borges. "Direito Autoral e Liberdade de Expressão Estudos de Direito"

. https://www.maxwell.vrac.puc-rio.br/18997/18997_6.PDF

.TOSCANO FRANCA FILHO, Maurício. O" GRAFITE E A

PRESERVAÇÃO DE SUA INTEGRIDADE: A PELE DA CIDADE E O "DROIT AU RESPECT" NO DIREITO BRASILEIRO E COMPARADO".

"Revista de Direito da Cidade", vol. 08, n 4, Página 8, ISSN 2317-7721. . https://www1.folha.uol.com.br/ilustrada/2017/11/1935197-artistas-podemser-indenizados-por-anuncio-de-carro-que-exibe-grafite.shtml

${ }^{43}$ Ibidem. Pág. 112. 
. BENJAMIN, Walter. "BENJAMIN E A OBRA DE ARTE". Cap.1 “A Obra de Arte na Era Da Sua Reprodutibilidade Técnica". Página 16. Editora Contraponto, 1 edição, 2015. . https://g1.globo.com/sao-paulo/noticia/avenida-23-de-maio-tera-oitoespacos-para-grafites-e-desenhos-velhos-serao-apagados-diz-doria.ghtml .LERMAN, Celia. "PROTECTING ARTISTIC VANDALISM: GRAFFITI AND COPYRIGHT LAW", "N.Y.U. JOURNAL OF INTELL. PROP. \& ENT. LAW". Vol.2:295

. PIXO” de direção de João Wainer, 2017, disponível em https://www.youtube.com/watch?v=skGyFowTzew . CAUQUELIN, Anne. "TEORIAS DA ARTE". TODAS AS ARTES, $1^{\mathrm{a}}$. Edição, 2005

. MATTOSO LOPES, Ana Carolina. "O Direito Social ao Lazer em

Perspectiva Crítica: Desigualdades e democratização do Acesso”, 2017 .http://vitruvius.com.br/revistas/read/drops/18.126/6925

. LÓPEZ ULLMANN, Carla. "LIBERDADE DE ACESSO À INFORMAÇÃO VERSUS DIREITOS AUTORAIS NA SOCIEDADE DA INFORMAÇÃO: A RESPONSABILIDADE CIVIL POR REPRODUÇÕES NA INTERNET" fls. 5

\section{LISTA DE IMAGENS}

Figura 1. Sonho de uma tarde dominical na Alameda, Diego Rivera (194748)

Figura 2. TAKI 183, Autor e obra.

Figura 3. ean-Michel Basquiat and Al Diaz's SAMOC tag. Photograph: (C) Henry A Flynt Jr

figura 4. "Crack is wack", Keith Haring. Photo: Global Street Art

Figura 5. Alex Vallari. Sem identificação. Retirada de https://notthesamo.co/2016/04/06/obras-de-alex-vallauri-ganhamexposicao-em-sao-paulo/

Figura 6. Eduardo Kobra no painel Etnias: maior do mundo Foto: Fabio Rossi/ Agência O Globo

Figura 7. "Em comercial, carro da Nissan passa em frente aos grafites"https://blogs.oglobo.globo.com/ancelmo/post/justica-condenanissan-por-aparicao-nao-autorizada-de-grafite-em-comercial.html

Figura 8. Obra de Kobra na 23 de Maio durante a política de "Cidade Limpa de Dória. Retirado de https://liberal.com.br/brasil-emundo/brasil/em-sp-painel-de-kobra-na-23-de-maio-amanhece-pichado517726/

Figura 9. Photo credit: Emmanuel Dunand/AFP/Getty Images 
